\title{
Agroecological transitions: What can sustainability transition frameworks teach us? An ontological and empirical analysis
}

\author{
Guillaume Ollivier $^{1}$, Danièle Magda $^{2}$, Armelle Mazé $^{3}$, Gael Plumecocq ${ }^{2,4}$ and $^{\text {Claire Lamine }}{ }^{1}$
}

\begin{abstract}
Transitioning toward more sustainable agricultural development paths requires extensive change and not simply marginal technical adjustments, as suggested by a strong conception of agroecology. To deal with transition, we believe that agroecology can be enriched by a deep analysis of sustainability transition frameworks and, conversely, that preexisting theories can be questioned in light of the specificities of agroecological transitions (AET). We first examine some of the main sustainability transition frameworks (resilience of social-ecological systems, institutional analysis and development of social-ecological systems, and socio-technical transition). We identify their ontologies to question their ability to be combined without deep adjustments. In a second step, we analyze how these frameworks have been used and questioned by researchers from the life sciences or social sciences in four AET studies. We find that each framework is relevant in its systemic and dynamic approach to change, but also that there are limits concerning the balance between the various dimensions. The scales and processes linked to AET must be taken into account, as well as the way to jointly consider ecological, socioeconomic, and technological aspects. Moreover, it is clear that problems in dealing with agency are common to these approaches, which influences the way to model change. More broadly, sustainability transition frameworks need to account better for ecological and technological materialities and processes, the importance of emergent organizations in singular situations, and learning processes and the diversity of knowledge dynamics. Doing so is challenging because it requires regrounding theories in empirical observations as well as questioning disciplinary frontiers and ontologies.
\end{abstract}

Key Words: agroecology; social-ecological systems; socio-technical systems; sustainability transition

\section{INTRODUCTION}

The ways in which agriculture has been developed have negatively affected the sustainability of global economies (IAASTD 2009). Because the agrifood industry contributes to economic growth and is deeply connected to standards of living, it is crucial for sustainability. Until now, technological innovations have not been able to trigger the vital changes required; on the contrary, the industrialization of agriculture has increased the levels of throughput used in the global economy (Krausmann and FischerKowalski 2013). To foster a transition toward more sustainable agriculture, alternative solutions have emphasized the positive role of (bio)diversification and the ecological processes and services they provide (Altieri 1999, Kremen et al. 2012). Whereas technological solutions extend the productivist paradigm, the strong conception of agroecology we refer to requires extensive changes in agricultural practices, in the organization of production and distribution, in the nature of technologies used, and in reconceptualizing the identity of "farmer" (Hill and MacRae 1996, Francis et al. 2003, Lamine 2011, Nicholls et al. 2016). Ultimately, these changes involve other sets of social norms, requiring a different conception of the humantechnology-environment situation than that prevailing in the productive, technology-intensive mode of agricultural production (Plumecocq et al. 2018). Agroecological transitions (AET) also imply cognitive aspects (IAASTD 2009). The knowledge used to manage technology-intensive production systems is no longer useful for informing individual and collective decision making in agroecological systems; however, tackling the complexity of the AET has analytical and scientific consequences.

As in agroecology (Altieri 1995, Gliessman 2011), different research approaches to transition increasingly address the issue of sustainability. The main sustainability transition (ST) frameworks belong to two families. The first, socio-technical transition (STT), includes many strands, among which transition management (TM) and multilevel perspective (MLP) are best known (Markard et al. 2012). The second family of socialecological system (SES) frameworks includes, among others (Binder et al. 2013), institutional analysis and development (IAD; Ostrom 2009) and resilience thinking (Holling 1978, Folke et al. 2010). Both groups of approaches emphasize the need to consider interactions among technical innovations, the structure and type of socioeconomic system, and ecosystem functions and services at multiple levels. In addition, even though agroecology contributes to sustainability, AET are rarely addressed in any of these approaches (Markard et al. 2012, Ollivier 2015). Agroecologists have not considered transition in a broad, systemic, and multilevel way because they have mainly conceptualized transition with the efficiency-substitution-redesign model at farm scale. This model, considering phases with increasing costs of system reorganization and ecological features integration, is sometimes applied to institutional dimensions (e.g., organizational design or role of social movements), mainly through descriptive accounts rather than social science theories (Hill and MacRae 1996, Gliessman and Rosemeyer 2010, Nicholls et al. 2016).

ST frameworks seem relevant for improving thinking about AET. However, to date, no study has analyzed the ontological and instrumental suitability of these approaches, combined or not, for addressing AET. Without trying to define a new integrated analytical framework, we seek here to identify some gaps and discuss future avenues for using and enhancing ST frameworks in transitioning agriculture toward sustainability. We argue that contrary to other types of transitions analyzed using ST

${ }^{1}$ ECODEVELOPPEMENT, INRA, 84000, Avignon, France, ${ }^{2}$ AGIR, INRA, INP-EI Purpan, INPT, Université de Toulouse, 31326 , CastanetTolosan, France, ${ }^{3}$ SAD-APT, INRA, AgroParisTech, 75005, Paris, France, ${ }^{4}$ LEREPS, IEP Toulouse, Université de Toulouse 1, Université de Toulouse 2, 31685, Toulouse, France 
frameworks (e.g., energy or water management), transiting to agroecological production systems faces the challenge of enrolling multiple and relatively isolated decision makers as well as nonhuman entities. This means that the ways in which the multiple issues of AET are tackled need to adequately consider the interactions among multiple levels of decision making, i.e., from a wide range of decentralized groups to more institutionalized organizations.

In the next section, we analyze some ontological mismatches of the main ST frameworks and identify debates and gaps in current research. Instead of reinforcing the understanding of sustainability issues, we conclude that a hasty combination of frameworks without critical reflection on their ontologies generates theoretical inconsistencies and the accumulation of each approach's limitations. We then present how AET are addressed by ST frameworks by investigating how they have been used in four studies on AET situations. These studies show that some adjustments of ST frameworks are required to better address AET. Based on the analysis of framework ontologies and their use in studies of AET cases, we then discuss avenues to analyze such transitions better: strengthening the links between socioeconomic, ecological, and technical aspects; integrating more agency into social-system thinking; taking ecological dynamics into account; and taking technology seriously.

\section{SUSTAINABILITY TRANSITION FRAMEWORKS ONTOLOGIES}

We focus on the two main ST frameworks: SES frameworks comprising resilience thinking (Holling 1973, Gunderson et al. 1995) and Ostrom's (2009) IAD, and STT. We chose these because they have been increasingly considered together in recent years, in publications, conferences, or international programs, in the larger field of sustainability science to explore the various aspects of ST (Leach 2008, Kajikawa et al. 2014, Ollivier 2015). Indeed, at first, the SES and STT literature share many interesting features: interest in sustainability, dynamic multilevel approaches to complex systems change, and learning (Voß and Bornemann 2011) and governance issues (van der Brugge and van Raak 2007, Smith and Stirling 2010). Some authors have tried to combine the frameworks (e.g., Pahl-Wostl et al. 2007, Duru et al. 2014, Pant et al. 2015), considering them to be complementary, but others have combined them with other frameworks to counter their limitations (Bush and Marschke 2014, Dwiartama and Rosin 2014, Fabinyi et al. 2014, Stone-Jovicich 2015). Nevertheless, as with other scholars (Shove and Walker 2007, Leach 2008), we call for caution in using, mixing, or integrating these frameworks because of the risk of ontological mismatches and limitations.

Considering their ontologies, in the epistemological sense, we aim to identify the problems that remain with these frameworks, particularly in their use for AET analysis, which we will examine in more detail below. Ontology is defined as the "foundational assumptions about the nature of the (social) world and its causal relationships" (Geels 2010) that underpin and frame ways of seeing transitions. Inspired by Geels (2010) and Binder et al. (2013), and considering history, anchorage, and critiques of frameworks, we identify in the following sections the main ontologies, their basic conceptual units, and their relations, which allow them to model reality in various ways in terms of disciplinary background; model of change; system delineation; and the social, ecological, and technological entities considered (Table 1).

\section{Resilience thinking of social-ecological systems}

The ontology of resilience thinking is based on recognizing the interdependence between people and nature (Folke et al. 2010), which is disruptive with the traditional ecology in which this approach was originally grounded (Xu and Marinova 2013). Resilience is a rejection of the "myth of ecological stability" (Holling 1978). The resilience concept allows the understanding of nonlinear dynamics of systems (Holling 1973), which constitutes a radical new way of seeing social-ecological reality.

For resilience thinking scholars, an SES is resilient when, faced with disturbances, it remains relatively stable and evolves within a "stability domain," defined as a set of controlling variables (Folke et al. 2010), itself embedded in a stability landscape. Under certain conditions (external shocks, crises, or changes in internal cumulative properties), some thresholds are exceeded, in which case, an SES can shift from one stability domain to another (Fig. 1A).

Fig. 1. Resilience thinking representation of social-ecological system dynamics. (A) Ball and cup heuristic of the stability landscape. (B) Panarchy model of adaptive and resilient change (adapted from Gunderson and Holling 2002).

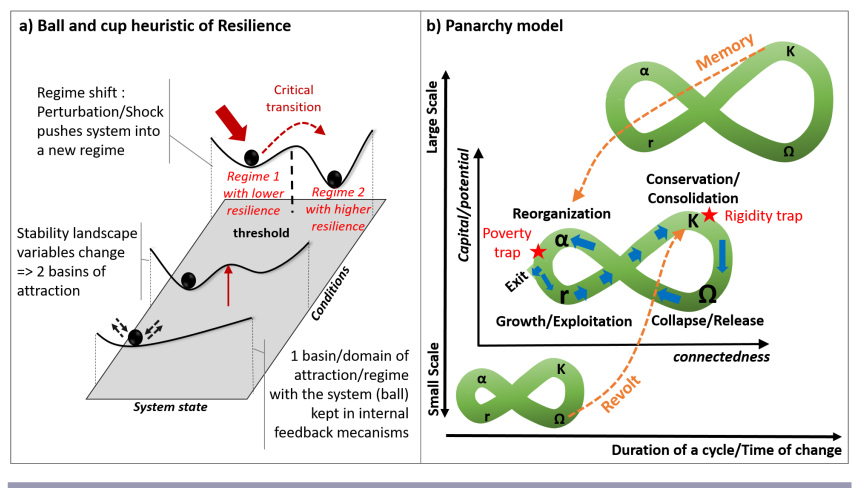

Drawing on studies of ecosystem changes (Holling 1986) and Schumpeter's work on technical innovation and economic cycles (Gunderson and Holling 2002, Allison and Hobbs 2004), some authors have described an SES trajectory according to the metaphor of an adaptive cycle. This way of considering time involves four endogenously driven, interlinked phases of change in SES structures and functions (Walker et al. 2004), separated by critical transitions (Scheffer 2009). In the growth/exploitation (r) phase, resources are freely available. This phase then merges into the conservation phase $(\mathrm{K})$ of slow capital accumulation, which then gradually becomes a rigid and low-flexibility phase in which most resources and novelty are locked up and are responsive to external shocks (Folke et al.2010). This phase would be "eventually, inevitably, followed by a chaotic collapse and release phase $(\Omega)$ that rapidly gives way to a phase of reorganization $(\alpha)$, which may be rapid or slow, and during which innovation and new opportunities are possible" (Walker et al. 2004). 
Table 1. Comparison of sustainability transition framework ontologies.

\begin{tabular}{|c|c|c|c|}
\hline \multirow[t]{2}{*}{ Ontological entity } & \multirow{2}{*}{$\frac{\text { Socio-technical transition framework }}{\text { Mainly multilevel perspective }}$} & \multicolumn{2}{|c|}{ Social-ecological system (SES) framework } \\
\hline & & Resilience thinking & Institutional analysis and development \\
\hline $\begin{array}{l}\text { Disciplinary } \\
\text { background }\end{array}$ & $\begin{array}{l}\text { Middle-range framework composed of } \\
\text { social science theoretical hybridization }\end{array}$ & $\begin{array}{l}\text { Pluridisciplinary approach first grounded } \\
\text { in ecology and later integrating economics } \\
\text { and social science disciplines }\end{array}$ & $\begin{array}{l}\text { Political science and institutional } \\
\text { economics }\end{array}$ \\
\hline $\begin{array}{l}\text { System } \\
\text { delineation }\end{array}$ & $\begin{array}{l}\text { Defined by the technology analyzed, so it } \\
\text { is continuously redefined through the } \\
\text { connections between levels }\end{array}$ & $\begin{array}{l}\text { Defined by physical materiality, so the } \\
\text { contours do not change }\end{array}$ & $\begin{array}{l}\text { Defined by a natural resource and social } \\
\text { dilemma treated within an action arena }\end{array}$ \\
\hline $\begin{array}{l}\text { Multilevel } \\
\text { conception }\end{array}$ & $\begin{array}{l}\text { Multilevel perspective triptych: landscape, } \\
\text { regime, and niche; mainly focused on niche } \\
\text { and regime coevolution }\end{array}$ & $\begin{array}{l}\text { Panarchy: interconnectedness, nested } \\
\text { adaptive cycles, and interactions within } \\
\text { and across scales (Folke et al. 2010) }\end{array}$ & $\begin{array}{l}\text { Polycentricity of nested social-ecological, } \\
\text { economic, and political systems }\end{array}$ \\
\hline Model of change & $\begin{array}{l}\text { Regime as a dominant and coherent set of } \\
\text { rules, social networks, organizations, and } \\
\text { prevailing infrastructure; path dependence } \\
\text { and technological lock-in: previous state of } \\
\text { the system determines its evolution; niches } \\
\text { as key drivers for change (Schot and Geels } \\
\text { 2007) }\end{array}$ & $\begin{array}{l}\text { Resilience as the target: maintenance of } \\
\text { system function and structure under } \\
\text { shocks; adaptive cycles and panarchy; } \\
\text { more recently, deliberate transformation of } \\
\text { SESs in unsustainable states; } \\
\text { transformative, small-scale experiments } \\
\text { and cross learning }\end{array}$ & $\begin{array}{l}\text { Nonlinear and cross-scale in time and } \\
\text { space, institutional and evolutionary } \\
\text { models of change (Ostrom 2007); } \\
\text { multitiered institutional diagnostic of SES } \\
\text { and of possible transformations; problem- } \\
\text { solving oriented and comanagement of } \\
\text { SES; transformative through changes in } \\
\text { users' knowledge, beliefs, and mental } \\
\text { models }\end{array}$ \\
\hline Governance & $\begin{array}{l}\text { Rules and routines; transition } \\
\text { management: given a target, adaptation } \\
\text { through the transformation path, niche } \\
\text { management }\end{array}$ & $\begin{array}{l}\text { Adaptive comanagement: adaptation of } \\
\text { institutions to circumstances due to } \\
\text { continuous learning (alignment principle); } \\
\text { adaptive governance (Folke et al. 2005, } \\
\text { Chaffin et al. 2014): individuals, } \\
\text { organizations, agencies, and institutions at } \\
\text { multiple organizational levels }\end{array}$ & $\begin{array}{l}\text { Adaptive and polycentric governance } \\
\text { (Ostrom 2010); formal and informal norms } \\
\text { and rules-in-use (operational, collective, } \\
\text { constitutional; Ostrom and Cox 2010); } \\
\text { missing institutions and institutional } \\
\text { barriers; collective action, social norms, } \\
\text { and connectivity of self-organized network } \\
\text { governance (McGinnis and Ostrom 2014) }\end{array}$ \\
\hline $\begin{array}{l}\text { Spatiotemporal } \\
\text { scales }\end{array}$ & $\begin{array}{l}\text { No spatial anchorage and various time } \\
\text { scales }\end{array}$ & $\begin{array}{l}\text { Very local or global; space and time are } \\
\text { fundamental }\end{array}$ & $\begin{array}{l}\text { Polycentric approach beyond local vs. } \\
\text { global; spatial anchorage linked to the } \\
\text { action situations and issues to be solved }\end{array}$ \\
\hline $\begin{array}{l}\text { Socioeconomic } \\
\text { system conception }\end{array}$ & $\begin{array}{l}\text { Macro and meso actors with a focus on } \\
\text { social groups defined according to their } \\
\text { functions (consumers, etc.); society is } \\
\text { produced by the intersection of structures } \\
\text { and agents (Giddens 1984); little analysis } \\
\text { of individual practices }\end{array}$ & $\begin{array}{l}\text { Focus on micro and meso actors: } \\
\text { individuals, institutions, communities, } \\
\text { networks; functionalist epistemology }\end{array}$ & $\begin{array}{l}\text { Dynamic view of policy processes in which } \\
\text { social, institutions, and biophysical factors } \\
\text { are inputs to the decisions made by } \\
\text { individuals; methodological individualism; } \\
\text { users' or actors' knowledge, institutions, } \\
\text { collective action, and rules }\end{array}$ \\
\hline Technology & $\begin{array}{l}\text { Constitutive of the system studied, mainly } \\
\text { energy macrosystems }\end{array}$ & Barely conceptualized & $\begin{array}{l}\text { Balancing a specific resource use and } \\
\text { system maintenance in the SES (McGinnis } \\
\text { and Ostrom 2014) }\end{array}$ \\
\hline $\begin{array}{l}\text { Ecological system } \\
\text { thinking }\end{array}$ & Ignored & $\begin{array}{l}\text { Central and in interaction with social } \\
\text { systems; from resource conceptualization } \\
\text { with no ecological system or process } \\
\text { elicitation }\end{array}$ & $\begin{array}{l}\text { Focusing on a specific natural resource, } \\
\text { dynamic ecological processes being treated } \\
\text { as exogenously given; not ecologically } \\
\text { explicit }\end{array}$ \\
\hline $\begin{array}{l}\text { Dimension } \\
\text { interactions } \\
\text { considered }\end{array}$ & Social $>$ technological $>$ (ecological $)$ & Ecological $>$ social $>($ technological $)$ & Social $>$ ecological $>$ (technological $)$ \\
\hline $\begin{array}{l}\text { Gaps and } \\
\text { criticisms }\end{array}$ & $\begin{array}{l}\text { Power and politics underestimated; ecology } \\
\text { and territory not considered }\end{array}$ & $\begin{array}{l}\text { Unbalanced analysis of social-ecological } \\
\text { interactions (Binder et al. 2013); narrow } \\
\text { conception of social dimensions; } \\
\text { technology not theorized; management of } \\
\text { changes not sufficiently addressed }\end{array}$ & $\begin{array}{l}\text { Misperceived static conception of rules } \\
\text { change; lack of normative clarity; } \\
\text { upscaling models }\end{array}$ \\
\hline
\end{tabular}

Moreover, the panarchy model (Gunderson and Holling 2002) considers change as the result of interactions of nested and multiscalar adaptive cycles (Fig. 1B). Rapid change at a small scale (revolt) can affect upper scales, but small-scale dynamics are also affected by upper scales that stabilize and conserve the accumulated memory of system dynamics (Folke et al. 2010).

For these authors, the resilience of the SES is the main goal for management (Berkes and Folke 1998, Olsson et al. 2004). However, some resilient systems may be locked in unsustainable states (Folke et al. 2010, Westley et al. 2011). SES scholars thus moved from their initial conservative focus toward the concept of transformability, defined as the ability to create a fundamentally new system in order to shift to more sustainable states (Walker et al. 2004) and even change the nature of the stability landscape (Folke et al. 2010). Transformational change at smaller scales enables resilience at larger scales. Such transformations require radical regime shifts in values, patterns of social behavior, multilevel governance, and management regimes (Olsson et al. 2014). 
As part of the resilience ontology and in response to the failure of "command and control" management (Holling and Meffe 1996), concepts of adaptive comanagement (Olsson et al. 2004) and adaptive governance (Folke et al. 2005, Boyd and Folke 2011) were developed. These processes imply that individuals and institutions are able to organize themselves in a learning-by-doing way, e.g., allowing them to adjust their actions and rules with regard to knowledge extracted from their environment (Olsson et al. 2004). Adaptiveness means developing connections and feedback between SESs and scales to enable collective learning to identify traps, learn from conflicts, find escape routes, and anticipate risks. Adaptive governance also points out two major challenges: overcoming legal and institutional barriers, and building bridges between current governance structures (Chaffin et al. 2014).

\section{Institutional analysis and the development framework of social- ecological systems}

The scope of SESs as seen by resilience thinking was progressively broadened to reinforce the conceptualization of social entities and their governance issues (Folke 2006, Binder et al. 2013, Xu and Marinova 2013, Brown 2014), mostly thanks to Elinor Ostrom and her attendance at seminars at the Beijer Institute organized by some resilience scholars (Ostrom 1993, Cleveland et al. 1996).

Ostrom conceived of IAD as an SES diagnostic tool, operationally oriented and prescriptive, and analyzing a range of collective action and social dilemmas related to common-pool resources (Ostrom 2009, McGinnis and Ostrom 2014). This framework is an SES with four interacting subsystems (Fig. 2): the resource system, the resource units (also called the biophysical conditions), the governance system, and the actors (previously called "users") embedded in the social, economic, political, and ecological settings that influence focal action situations (Ostrom and Cox 2010, McGinnis and Ostrom 2014).

Fig. 2. Institutional analysis and development representation of social-ecological systems. Source: Ostrom and Cox (2010).

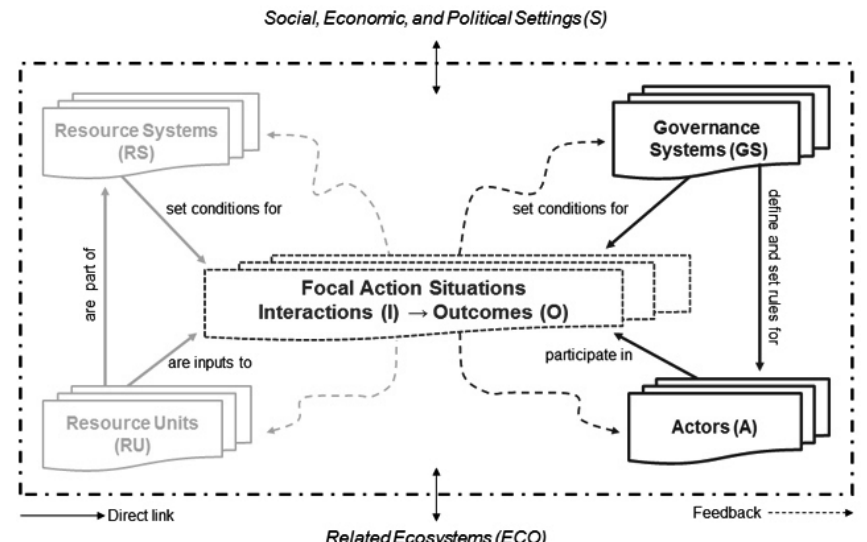

IAD includes strategies that go beyond nested property rights systems, considering concepts of social capital (trust, networks, cooperation), cultural capital for maintaining practices and learning, knowledge systems and mental models, enhancement of user rights, power and qualification, and access to market, capital, and investments (Ostrom 2009). By highlighting the danger of blueprint solutions (Ostrom and Cox 2010), IAD stresses the notions of "missing institutions" and possible scale mismatches in the face of disturbances (Cleveland et al. 1996, Ostrom 2010). Beyond markets and states, Ostrom puts forward the concept of polycentric governance to better contextualize multiscale resource management (Young et al. 2006, Ostrom 2010). Polycentric governance emphasizes the coexistence of many centers of decision making and power with authority divided among overlapping jurisdictions that are formally independent of each other (McGinnis and Ostrom 2014). Polycentricity and networked forms of self-governance enable community users to develop rules and organizations at multiple levels and better mutual adjustments between social and ecological systems compared to monolithic, external, and imposed rules (Ostrom and Cox 2010).

\section{Socio-technical transition frameworks}

STT frameworks emerged in the Netherlands in the 1990s and have gained interest since the mid-2000s. Interest in them is now growing internationally through the Sustainability Transitions Research Network (established in 2009) and its journal Environmental Innovation and Societal Transitions (established in 2011). The network's Board is a meeting point of various ST frameworks, especially STT, SESs, and industrial ecology (van den Bergh et al. 2011).

STT scholars build conceptual frameworks to analyze the coevolution of society and technology, borrowing from many theories in the social sciences (Geels 2011, van den Bergh et al. 2011, Markard et al. 2012): constructivist science and technology studies (Hughes 1983, Bijker et al. 1987), evolutionary economics (Dosi 1982, Nelson and Winter 2002), new institutional economics (North 1990, Williamson 1996), and structuration theory (Giddens 1984). The two main STT frameworks are MLP (Geels 2002, 2011), which is an analytical framework for understanding past transitions (Fig. 3), and TM (Rotmans et al. 2001), which deals with governing transition toward a specific sustainable goal. The TM approach is often discussed within the SES literature because of its approach to governance (Binder et al. 2013).

MLP analyzes transitions defined around a particular technology. As in the panarchy model, MLP conceptualizes nested levels of change but does so through interactions among three specific scales: the socio-technical landscape, the regime, and niches (Fig. 3 ). Transition is the process of regime reconfiguration under the action of the landscape and the ability of niches to be integrated in the dominant socio-technical regime. The landscape level represents the exogenous economic, political, and cultural contexts beyond the influence of niche and regime actors (Geels 2002, 2011). Niches are defined as spaces on the margins of the dominant regime where small networks of actors develop radical innovations. For MLP scholars, in the dominant regime, established routines, practices, and rules within a set of coherent and interdependent dimensions (technology, policy, etc.) stabilize existing sociotechnical systems. Some studies in STT, based in evolutionary economics (David 1985, Arthur 1989, Cowan and Gunby 1996), also analyze transition failures through the processes of path dependency and lock-in of the technological system, which explain the regime's stability (Berkhout 2002, Vanloqueren and Baret 2008, Foxon 2011, Geels 2014). 
Fig. 3. The multilevel view of transitions. Adapted from Geels (2002).

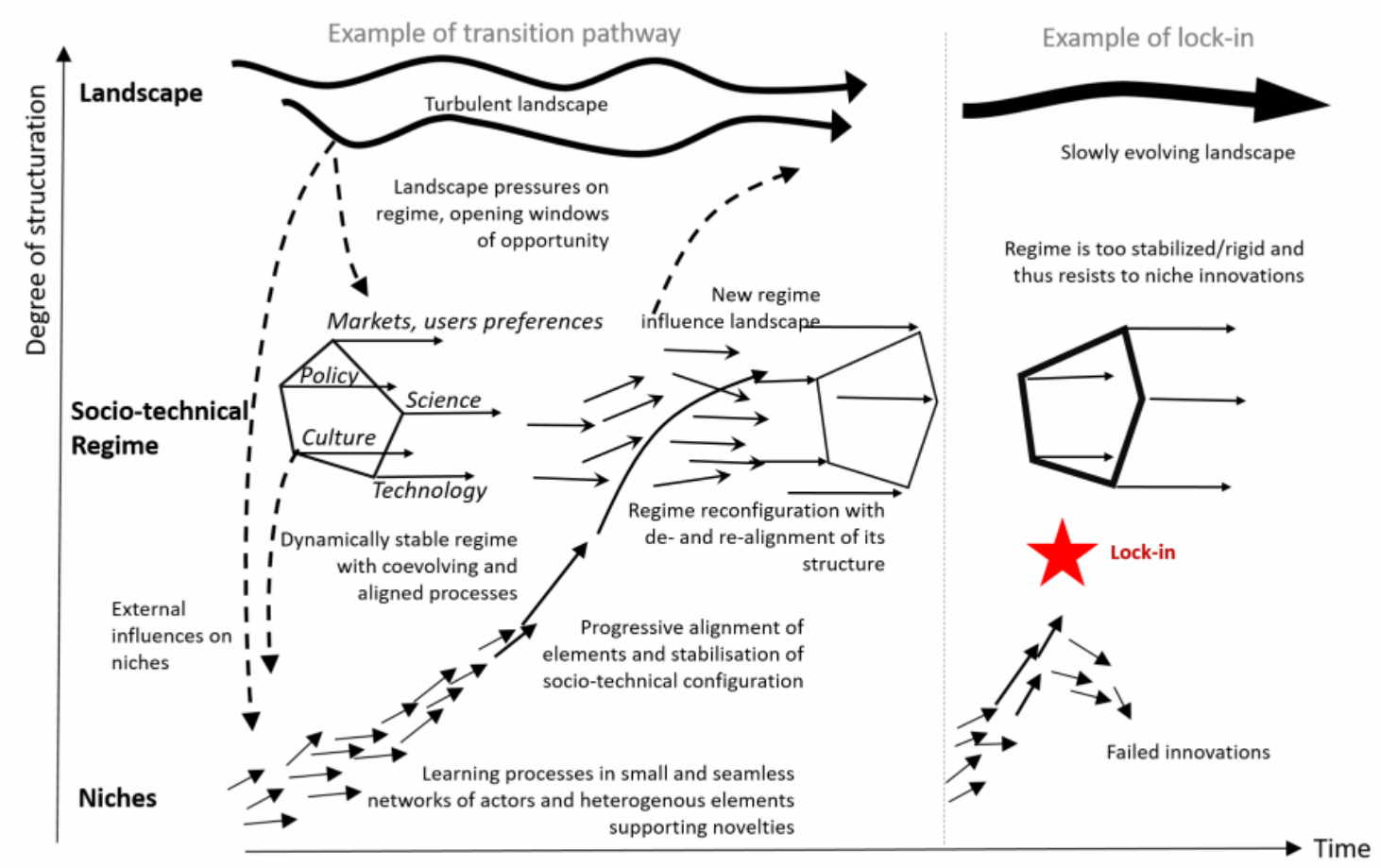

\section{Concluding remarks: the need to return to ontologies}

Our overview of framework ontologies according to the items chosen highlight some common points, but primarily the specificities, of each framework (Table 1). We identify critical points for each framework, which are sometimes common to many of them (e.g., agency and power issues) and sometimes unique (e.g., lack of consideration for some dimensions). All of these issues are limitations to integrating these frameworks fully. We identify some key ontological mismatches between frameworks that will be analyzed further in the general discussion. We have already noted that SESs and STT make many analogous contributions, for instance, on systemic or multilevel analysis.

In recent years, some scholars in each group have suggested convergences between ST frameworks. For instance, the notion of transformability in resilience thinking allows for some convergences with STT. Transition here seems analogous to the panarchy mechanism of revolt that contaminates upper levels and stabilizes system dynamics. Transition can also be compared to deliberate transformation or regime shift in the SES resilience framework (Moore et al. 2014). In some cases, the socio-technical system can be so resilient in the SES sense that it is locked in an unsustainable state. Thus, technological lock-in analysis can be inspired by concepts of pathological states of poverty, rigidity, and lock-in traps of adaptive cycles in resilience thinking (Allison and Hobbs 2004).

Although such convergences may be promising, when analyzing their ontologies more deeply, we find that their conceptualizations of system, scales, model of change, and social and ecological entities are not identical. Moreover, they are sometimes contradictory, and there may be some confusion about concepts that are used in several approaches but have different meanings (e.g., niche, regime, or transition).

For instance, concerning system delineation, the defining criterion in each framework is not the same, and the entities composing the systems are always partially considered in regard to particular conceptual and disciplinary ontologies. There are always some dimensions that are not fully taken into account, which leaves potential blind spots in system analysis (e.g., technology in resilience or ecology in STT). STT approaches mainly focus on the relationship between technical and socioeconomic systems, whereas SES approaches tend to neglect the technical dimension of human-nature interactions.

These respective gaps and unknown or underconceptualized entities can be seen as possible sources of complementarity between frameworks, for instance, taking the ecological ontology of resilience thinking to reinforce STT approaches that are more focused on technology. However, we argue that this kind of integration must be done carefully because there are some ontological mismatches on many points between frameworks that must be considered. For instance, concerning conceptions of change, when resilience is considered as a finality for a system, this induces confusion with the concept of transition, which implies a radical change, and not system stability. There is also a mismatch in time conceptions between the cyclicality of panarchy, the teleology of STT, and the lack of temporality of IAD.

Concerning the multilevel conceptions, there is also a mismatch among, and even within, frameworks. Indeed, even though there is a nested hierarchy in MLP, the functional qualification of levels differs from the hierarchy of nested scales of the panarchy model 
and the polycentricity of IAD. Geels (2011), in response to critics of MLP, mentions "theoretical inconsistencies" due to the progressive introduction of relationist and "flat ontologies" in the framework, which was first conceived as a nested hierarchy. These evolutions of MLP also refer to changes in the social ontologies it hybridizes by borrowing from various social science schools. The three frameworks considered also refer initially to a functionalist ontology (Gunderson and Holling 2002, Genus and Coles 2008, Geels 2010, Hatt 2013). Functionalism emphasizes structures, functions, and mechanisms that maintain the system's cohesion, consensus, and order, while conflict is denigrated (Catton and Dunlap 1980). Functionalist approaches are all criticized for their narrow conception of socioeconomic dynamics, particularly concerning issues of agency, conflict, and power relations (Shove and Walker 2007, Stone-Jovicich 2015), which prevents conceptualizing potential drivers of change.

ST frameworks offer conceptual and theoretical features to better tackle systemic and multilevel mechanisms of transition. However, we argue that the integration of these frameworks needs reconceptualizations that take into account their ontologies, foundational assumptions, and possible mismatches. To deepen the discussion about ways to enhance ST analysis, particularly in the case of agricultural sustainability, we next present how AET case studies challenge the use of these frameworks.

\section{APPLYING SUSTAINABILITY TRANSITION FRAMEWORKS TO AGROECOLOGICAL TRANSITION SITUATIONS}

Here, we critically examine research designs that question how SES (IAD and resilience versions) and STT (mainly MLP) frameworks have been used by researchers to address AET. Four case studies were identified based on academic publications (Deconchat et al. 2007, Souchère et al. 2010, Lamine 2012, Bui 2015, Magrini et al. 2016) and were supplemented with interviews with the main authors about their use of and possible adjustments to ST frameworks. The cases were selected because, together, they provide a broad and concrete overview of various aspects of AET as well as different ways to analyze them (Table 2 and Fig. 4). The objective was to reveal the practical limits and adjustments of these frameworks when used to address AET issues, in particular emphasizing: (1) their distinctive linking of socioeconomic, technical, and ecological dimensions to varying degrees (Fig. 4); and how they deal with (2) technology; (3) conflicts and power relationships; and (4) ecological functioning. Each of these studies was conducted by researchers from different disciplines. Moreover, they also differed in their combinations of viewpoints and goals as a result of their epistemological posture, revealing different possible uses of ST frameworks (Table 2 and Fig. 4).

\section{Gascony hillside forest management study}

In this study, the researchers analyzed forestry practices in the Gascony hill country in southwestern France. In this agricultural region, forest management provides pest regulation services and reduces farmers' dependence on chemicals. The aim of the study, grounded in a vision of AET at landscape level, was to understand how standard management of a coppice (the main silvicultural system in the Gascony region) could contribute to both sustainable agriculture and forestry. The SES resilience approach was used to describe the forest (as a shelter, a support for biodiversity protection, and an object of management;
Deconchat et al. 2007). Thus, the forest was conceptualized as an SES, linking ecological functions and properties (biodiversity, population regulation, etc.) with social dimensions (forest as a heritage site, production system, product of practices, etc.). The study focused on landscape management practices because they were seen as a link between social systems and ecosystems. More precisely, the researchers studied how several biodiversity patterns were influenced to varying degrees by human practices (mainly logging) and natural factors (e.g., edaphic conditions, dispersal).

Various adaptations were needed in applying the resilience approach:

1. At the epistemological level, the resilience framework was not completely adopted by the authors because they thought it would not provide an analytical basis for establishing or testing their hypothesis (i.e., that forest management can contribute to biodiversity at the landscape level and limit the use of chemicals in surrounding agriculture). In general, they agreed it was not possible to use hypothetico-deductive reasoning in the resilience approach when dealing with largescale issues or landscape matters. According to the authors, this is because it is not possible to control all parameters described in this framework at a larger landscape scale and because complexity makes it unsuited for revealing chains of causality (interlinks of direct and indirect effects). Instead, the resilience approach was used in a more inductive and exploratory way to frame the interdisciplinary work among sociologists, geographers, landscape ecologists, and entomologists. This approach also facilitated agreements on the shared ideas underlying the study, e.g., acknowledging that social systems and forest ecosystems coevolve because the rules of management are codetermined.

2. The authors found that identifying multiple levels was not helpful when dealing with AET. When considering the large scale, biodiversity management issues required taking into account multiple scales and the ways in which those scales were interconnected. In particular, specialized land uses at local scales (e.g., forest or agriculture) may reveal a much more diverse patchwork at larger scales. In the resilience framework, multilevel connections are conceptualized as hierarchical (see the nested adaptive cycle from the panarchy model). Therefore, it misses the effects of leaps across scales and patchwork effects. However, greater plasticity in interpreting connections at various scales is important for plant biodiversity and is even more crucial for animal biodiversity because animals are mobile.

3. Ecological system thinking needed refinement. The study highlighted the importance of the fringes of different landuse areas and geographical units (e.g., edges of woodlots or parcel rims) in which significant social-ecological issues arise. If we do not explicitly take into account fringe areas, we cannot truly understand how biodiversity operates as a link across various areas.

4. Socioeconomic system thinking was found to be too cursory. The study found that the rules conventionally accepted by ecologists to manage the forest and biodiversity in an ecologically rational way were not applied by the stakeholders, who kept doing as they had always done. 
Table 2. Comparison of agroecological transition studies.

\begin{tabular}{|c|c|c|c|c|}
\hline \multirow[b]{2}{*}{ Study aspect } & \multicolumn{4}{|c|}{ Case study and framework used } \\
\hline & $\begin{array}{l}\text { Gascony hills forest } \\
\text { management } \\
\text { Social-ecological systems } \\
\text { (resilience thinking) }\end{array}$ & $\begin{array}{c}\text { Erosion Caux, Normandy } \\
\text { Social-ecological systems } \\
\text { (institutional analysis and } \\
\text { development) }\end{array}$ & $\begin{array}{c}\text { Biovallee, Drôme } \\
\text { Socio-technical transition } \\
\text { (multilevel perspective [MLP]) }\end{array}$ & $\begin{array}{c}\text { Legume crops, France } \\
\text { Socio-technical transition (MLP) }\end{array}$ \\
\hline $\begin{array}{l}\text { Research } \\
\text { question }\end{array}$ & $\begin{array}{l}\text { How to improve forest } \\
\text { management by implementing } \\
\text { innovative forestry techniques? }\end{array}$ & $\begin{array}{l}\text { How to reduce the negative } \\
\text { impacts of soil run-off at the } \\
\text { watershed level in a mainstream } \\
\text { cereal-growing agricultural } \\
\text { area? }\end{array}$ & $\begin{array}{l}\text { How has organic farming been } \\
\text { developed in a territory where } \\
\text { numerous alternative initiatives } \\
\text { coexist with mainstream ones? }\end{array}$ & $\begin{array}{l}\text { How can actors develop legume } \\
\text { food chains and revive pulse } \\
\text { crops? }\end{array}$ \\
\hline Scholar posture & $\begin{array}{l}\text { Inductive and exploratory; } \\
\text { symmetry between ecological } \\
\text { and social system }\end{array}$ & $\begin{array}{l}\text { Companion modeling } \\
\text { (COMMOD) }\end{array}$ & Analytical & Descriptive and analytical \\
\hline $\begin{array}{l}\text { Disciplinary } \\
\text { background }\end{array}$ & Ecology and ethnology & Agronomy and ecology & $\begin{array}{l}\text { Sociology, mainly MLP and } \\
\text { actor-network theory }\end{array}$ & $\begin{array}{l}\text { (Socio)economics, agronomy, } \\
\text { MLP as a heuristic device for } \\
\text { interdisciplinarity }\end{array}$ \\
\hline $\begin{array}{l}\text { System } \\
\text { delineation }\end{array}$ & $\begin{array}{l}\text { Forest management practices in } \\
\text { the studied area }\end{array}$ & $\begin{array}{l}\text { Farm management issues at a } \\
\text { watershed level }\end{array}$ & Territorial agrifood system & French legumes agrifood chain \\
\hline $\begin{array}{l}\text { Multilevel } \\
\text { conception }\end{array}$ & $\begin{array}{l}\text { Analysis at the landscape level } \\
\text { while accounting for different } \\
\text { land-use interactions and social } \\
\text { representations; sample areas } \\
\text { chosen "in such way that they } \\
\text { were superimposed as much as } \\
\text { possible and nested" }\end{array}$ & $\begin{array}{l}\text { Nonhierarchical multitiered } \\
\text { approach of the variables } \\
\text { affecting the social-ecological } \\
\text { system, as well as its multilevel } \\
\text { or polycentric governance } \\
\text { approach, by identifying the } \\
\text { multiple key stakeholders } \\
\text { involved }\end{array}$ & $\begin{array}{l}\text { Analysis of diverse local niches } \\
\text { and their influence on the } \\
\text { regime }\end{array}$ & $\begin{array}{l}\text { Standard conception of MLP } \\
\text { framework; focus on lock-in } \\
\text { effects }\end{array}$ \\
\hline $\begin{array}{l}\text { Model of } \\
\text { change }\end{array}$ & $\begin{array}{l}\text { Slow changes of individuals; } \\
\text { inherited local socio-cultural } \\
\text { representations }\end{array}$ & $\begin{array}{l}\text { Changes from individual eco- } \\
\text { socio-technical mental models } \\
\text { to individual actions and } \\
\text { required collective negotiations }\end{array}$ & $\begin{array}{l}\text { Change relies on the progressive } \\
\text { legitimation and coexistence of } \\
\text { niche initiatives inspired by a } \\
\text { radical ecologization paradigm } \\
\text { and more conventional } \\
\text { stakeholders' initiatives } \\
\text { endorsing an ecological } \\
\text { modernization paradigm }\end{array}$ & $\begin{array}{l}\text { Rooted in evolutionary } \\
\text { economics (path dependency); } \\
\text { change driven by technical } \\
\text { innovations (as a system); } \\
\text { coevolution between various } \\
\text { dimensions and levels of the } \\
\text { systems }\end{array}$ \\
\hline $\begin{array}{l}\text { Spatiotemporal } \\
\text { scale }\end{array}$ & $\begin{array}{l}\text { From long-term, slow } \\
\text { incremental ecological changes } \\
\text { to faster cutting practices and } \\
\text { social opportunities; current } \\
\text { practices accounting for } \\
\text { vernacular uses }\end{array}$ & $\begin{array}{l}\text { Defined by the time needed to } \\
\text { implement the technical } \\
\text { solutions identified (here } 12-18 \\
\text { mo to change crop rotations) or } \\
\text { as iterative periods of } \\
\text { adjustments and replication }\end{array}$ & $\begin{array}{l}\text { Territory as political- } \\
\text { administrative boundaries that } \\
\text { shape actors' interactions; study } \\
\text { of ecologization processes } \\
\text { requires analysis at two main } \\
\text { temporal scales = four decades } \\
\text { (socio-historical analysis), } 5 \mathrm{yr} \\
\text { (direct observation through } \\
\text { fieldwork) }\end{array}$ & $\begin{array}{l}\text { National scale; long term (regime } \\
\text { construction and lock-in; various } \\
\text { temporalities across different } \\
\text { levels of the social system) }\end{array}$ \\
\hline $\begin{array}{l}\text { Socioeconomic } \\
\text { system } \\
\text { conception }\end{array}$ & $\begin{array}{l}\text { "The social system is } \\
\text { traditionally organized in } \\
\text { 'houses' that correspond to } \\
\text { well-identified land domains, } \\
\text { names, and social roles, which, } \\
\text { in particular, determine the } \\
\text { inheritance process... and } \\
\text { cooperative relations between } \\
\text { neighbors" }\end{array}$ & $\begin{array}{l}\text { A simplified version of social } \\
\text { and economic rules is integrated } \\
\text { into a role-playing game } \\
\text { through preidentifying key } \\
\text { actors based on their function } \\
\text { (farmers, watershed managers, } \\
\text { extensionists), rules-in-use, and } \\
\text { power relations at play }\end{array}$ & $\begin{array}{l}\text { Focus on interactions between } \\
\text { local actors and power relations } \\
\text { that are transformed because } \\
\text { alternative actors make } \\
\text { alliances and gain influence }\end{array}$ & $\begin{array}{l}\text { Institutional set-up progressively } \\
\text { constructed over time; } \\
\text { institutions frame collective } \\
\text { behaviors and promote (or } \\
\text { discourage) particular modes of } \\
\text { organization }\end{array}$ \\
\hline $\begin{array}{l}\text { Technology (and } \\
\text { technical } \\
\text { practices) }\end{array}$ & $\begin{array}{l}\text { Techniques are the main driver } \\
\text { of change in land use (from } \\
\text { cutting trees to agriculture) }\end{array}$ & $\begin{array}{l}\text { Techniques, and possible } \\
\text { adjustments to the social- } \\
\text { economic system, are the focus } \\
\text { of a role-playing game to assess } \\
\text { the collective effects of } \\
\text { individual decisions of involved } \\
\text { farmers and to identify the best } \\
\text { collectively agreed-upon } \\
\text { solutions }\end{array}$ & $\begin{array}{l}\text { Adoption of organic farming } \\
\text { practices was key for some } \\
\text { initiatives in the region, but } \\
\text { social and organizational } \\
\text { innovations were more central } \\
\text { in the approach }\end{array}$ & $\begin{array}{l}\text { Technology, a fundamental } \\
\text { dimension of lock-in, plays an } \\
\text { important part in aligning niches } \\
\text { and regimes }\end{array}$ \\
\hline
\end{tabular}




\section{Ecological system thinking \\ The forest is conceived of as an ecosystem and as a managed habitat supplying services to adjacent agricultural activities}

\section{Dimension} interactions considered Gaps and criticism
Ecological - technological social

Does not account for the different ways organizational levels interact; does not account for some social dimensions (related to ethnology); cannot be used to test hypotheses
Initial conceptual model addresses only specific natural resources (water and soil erosion), identified as problematic, while keeping a mainstream approach to the design of farming systems Technological - socioeconomic $>$ (ecological)

Limitations of modeling: complex conception and use, which limits replication; lack of analysis of rules change and upscaling processes; lack of follow up on the effective implementation of solutions found
No ecological system thinking applied to the agrifood system as a whole within this approach

Ecological system is not considered as such: environmental benefits are taken for granted, and nitrogen fixation is considered an exogenous variable of the problem

Social $>$ (technological $)>$ (ecological) Social - technological > (ecological)

Limitations of the MLP framework: power relations, change mechanisms (how rules and practices are driven to change), ecological dimensions

MLP is insufficient for understanding: how regimes are locked in, how niches integrate regimes, the means by which actors from niches and regimes can cooperate, the links between niche and landscape
Extensive ethnological research indicated that the "less rational" management rules that forest managers chose for themselves were based on vernacular practices deeply rooted in systems of beliefs and modes of representation of the forest, e.g., as a heritage site in which socio-cultural characteristics are embedded, rather than as capital to be exploited. The authors noted that researchers need to consider the effects of confronting the regulation system with the belief system because the latter is considered irrational from an ecologist's perspective.

\section{Pays de Caux soil run-off study}

In this study, the researchers analyzed the management of soil run-off at the watershed level in the northwest European belt region (Pays de Caux, Normandy, France; Souchère et al. 2010). This region is one of the most productive agricultural areas of France, with highly specialized crop systems. It is also subject to erosive phenomena involving episodic deadly muddy floods, as well as pollution of the water supplied to surrounding large cities. The researchers sought to find ways to improve territorial organization to better manage erosion and soil run-off through an agroecological perspective. To this end, the authors used companion modeling (COMMOD) methodology grounded in Ostrom's SES approach (Étienne 2014), using multiagent modeling and role-playing games (Janssen and Ostrom 2006).

Using the COMMOD methodology had two aims. The first was to push stakeholders to establish a clear, realistic, and agreedupon vision of possible changes in situated contexts through a visioning and anticipating exercise. The second objective was to help a diverse group of stakeholders with multiple and conflicting views work together. The goal was to foster collective decision making by allowing the participants to assess the collective effects of individual decisions and of neighborly relationships on problems of soil run-off in a large cereal-growing area. The authors built a conceptual model of the social-agro-ecological system used during the role-playing game by drawing on recent advances in soil science and agronomy as well as social, economic, and political inputs and related ecosystem variables (Ostrom 2009).

The role-playing game presented a watershed area. Three farms were located there. The outflow of their water catchment was located in a built area of a village. The spatial grid was $400 \mathrm{~m}^{2}$ per pixel and included all the parceled plots of the three farms. A three-crop rotation system was applied for each land plot, with wheat, potatoes, and peas. Depending on the crop management sequence, different levels of soil run-off were modeled (for example, for rolled and nonrolled peas). The price was fixed by the cooperative. Because rolled peas are considered "greener," they were given a price premium. The computing simulation model then calculated the transfer of run-off from one land plot to another at a lower level. Depending on the volume of run-off observed, technical solutions (change farmers' crop management sequences or install hydraulic infrastructure such as grass strips or rainwater collection reservoirs) or economic solutions (taxes for bad practices, financial compensation for good practices, etc.) were designed. Six people participated in the role-playing game. It started with the coconstruction of a conceptual model from the knowledge participants acquired in education programs on soil erosion. In a second phase, the game followed a two-step sequence: first defining crop management rotation over a threeyear period at an individual level, and then modifying decisions after concertation and negotiation.

The socioeconomic system was represented by the different relevant stakeholders needed for preventing and resolving soil run-off: the farmers located in the watershed, the watershed technical manager, the representatives of local public authorities (village, city, large metropolis), nongovernmental organizations (consumers), landowner unions, an agricultural council, and the river basin agency. All of these stakeholders defined the action arena modeled during the cooperative role-playing game. The model was first tested in a small area before changing scale and being applied to other watersheds in the river basin, thus covering a larger geographical area.

Diverse limitations emerged with the COMMOD methodology as an IAD approach of SES study:

1. Whereas ecological system thinking and technology seem to be integrated, the AET analyzed in and promoted by this study was primarily driven by the reflexive learning and local adaptive management of the SES. This was the case with regard to specific agronomic practices (crop rotation, cover crops) and the infrastructure needed to prevent soil run-off 
Fig. 4. Position of the selected case studies according to the socioeconomic, ecological, and technological dimensions studied.

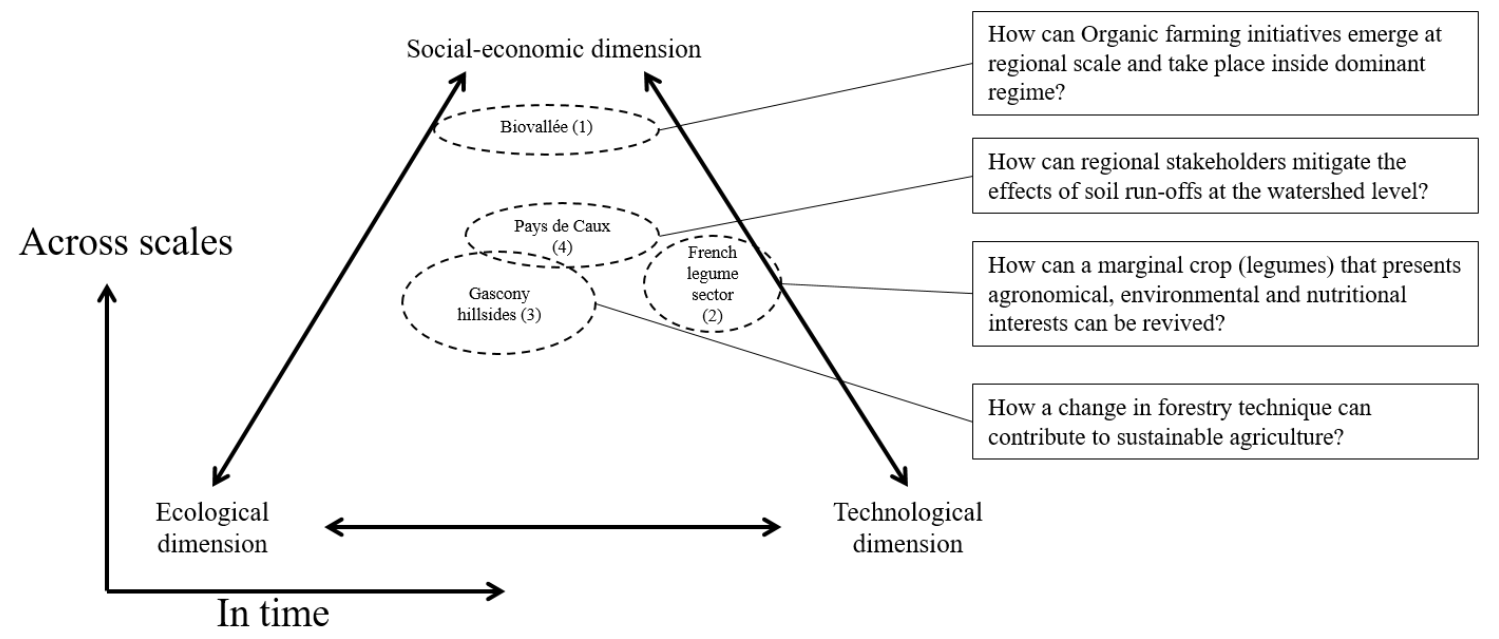

(grass strips, rainwater collection reservoir), as well as the economic trade-offs at stake. The initial design of the conceptual model played a key role in the COMMOD methodology, questioning both the nature of the "ecological knowledge" included in the conceptual model and the way it was built and experienced by stakeholders (Folke 2006).

2. The outcomes of the role-playing game largely depended on the ability of the research team to preidentify potential sources of conflict and power relations and to involve the various key stakeholders in solving the ecological issues identified. Without accurate preidentification, the solutions identified during the role-playing game may not be effectively implemented in the field if barriers to their implementation have not been removed.

3. The multiple levels of time and space and their interconnections remained challenging. Over time, the authors identified a number of issues in maintaining a shared collective and spatial representation of erosion problems. This was especially true because the context involved changes in people and society (a farmer's retirement, resignation of watershed managers, elections) and in farming practices. This in turn affected the efficiency of the solutions identified in different time frames, as well as their possible extension to a larger geographical scale across multiple interdependent watersheds with different water supply agencies and local authorities. The underlying model of change within the SES was incremental, addressing the micro-situational variables affecting farmers' decision making and local patterns of collective action. Preanalytical choices might have meant the silencing of radical change within the socio-agro-ecological systems through the interactions among socioeconomic, technical, and ecological aspects. Instead, local actors were left free to negotiate individually and collectively and to decide on the solutions they wanted to implement. Nevertheless, path dependencies imposed by the broader socioeconomic, institutional, and political context were not challenged in modeling the SES and its sustainability over time.

\section{Biovallée study}

In this study, the researchers examined the development of organic farming in the Drôme valley, a mountainous rural area in southeastern France. Because of the diversity of local farming systems (field crops, seeds, fruits, garlic, goat, sheep, aromatic and medicinal plants, vegetables, and wine), there is little intensive use of chemicals on this area's farms, except in the flat valley area. This region was one of the birthplaces of organic farming in the 1970s in France. In the early 1990s, the area was affected by rural exodus, lack of competitiveness, and agricultural crises. Organic farming then became a way to sustain local agriculture. According to stakeholders, local policies were implemented to turn this "hinterland of productivism" into "a pioneer of the quality turn." Between 2009 and 2014, the four communities of towns in the valley implemented a public program named Biovallée to boost sustainable development. This strategy involved linking several domains in technology and ecology such as ecobuilding or farming and food, which were key areas for action.

The researchers examined the factors that fostered organic farming and the extent to which this transition process involved several components of the region's agrifood system; i.e., not only farming practices, but also processing, retailing, and consumption practices (Lamine 2012, Bui 2015). The analysis was partly based on the MLP framework used to study AET mechanisms. Following the evolution of public policies over the preceding four decades, as well as several key initiatives launched by the local agricultural cooperatives and by diverse actors within the local civil society, the study uncovered changes in the visions of and the rules within the agrifood regime over time. The researchers found that organic farming progressively became an option on which the diverse actors in this territorial agrifood system converged, although in two different paradigms: one outside the regime (the paradigm of radical ecologization, endorsed by civil society actors), and one inside it (an ecological modernization 
paradigm endorsed by more conventional economic stakeholders such as the cooperatives). Both paradigms were also supported by local public policies. The study thus showed that AET at the scale of a territorial agrifood system resulted from a combination of private and civil society initiatives and tailored public policies, which, in turn, led to further legitimation of both ecologization paradigms.

However, the researchers had to address some shortcomings of the MLP approach:

1. MLP does not give enough attention to social or organizational innovations, which were decisive in the Biovallée agroecological transition. Whereas MLP primarily focuses on technological innovation and considers that niches can influence the regime by selection through technological competition, the researchers also included social innovations in the study to capture the complex process of AET in this area.

2. The researchers found that niches were not in competition as would be expected from MLP. Rather, the transition involved diverse niches that coexisted and interacted with the regime (separately or together). These different initiatives were able to influence the regime because each of them affected several (different) components of the territorial agrifood system (farming practices, processing, retailing, consumption practices, extension services, research), even though each initiative may have significantly affected only one or two components.

3. An important point deals with one of the main criticisms of the MLP approach: the fact that it neglects power relationships. The researchers addressed this issue by using actor network theory to study enrolment processes and alliances. They showed that in Biovallée, AET were made possible because alternative actors progressively gained more influence (especially with the local authorities), which resulted in redefining power relationships within the territorial agrifood system, especially between mainstream and alternative agricultural actors.

In summary, this study showed that transition processes did not result from technological innovation developed within niches, but rather from various initiatives that generated social innovations and through a profound redefinition of the visions and power relationships, which were territorially grounded.

\section{French legumes agrifood study}

In this study, the researchers analyzed the legume agrifood chain (from production to distribution) in France (Magrini et al. 2016). Although legume crops can contribute to AET through the nutritional (protein) and ecological (nitrogen fixation) benefits they provide, their area of cultivation in France is decreasing. The MLP approach was used to examine how to revive legume crops. This framework was considered adequate for describing the problem at hand: How can a beneficial but marginal crop emerge from organizational or technical innovations (e.g., extruded protein for livestock feed or legume-durum wheat pastas)? MLP was also used as a heuristic framework to facilitate interdisciplinary research: economists and agronomists agreed on the elements involved in the transitions described in MLP. As the study progressed, however, it became clear to the researchers that understanding how to revive this crop required analyzing why it had decreased in the first place and the factors that locked legume crops in a marginal position. The researchers thus decided that a more in-depth examination of the historical processes leading to this lock-in was necessary. In this respect, the MLP proved to be relatively insufficient because it does not fully clarify how sociotechnical systems become locked in. Therefore, as the research moved toward examining these lock-in mechanisms, the authors drew more on evolutionary economics, in particular Arthur (1989), and the notion of anchorage (of niches within regimes).

In the type of AET analyzed, the emergence of niches and their evolution played a significant role. In the MLP, niches are perceived as places where innovation takes place, which can change the course of a socio-technical regime. For this reason, the authors of this study were limited in their use of the MLP framework in several ways.

1. In MLP, emphasis is placed on the role of technological innovations but tends to neglect other kinds of (social) innovation. Innovations require networking the actors and organizing collective action. However, forms of social organization may also be considered innovative; for instance, they can be designed to provide, justify, and support the provision of agronomic services (e.g., using legume as an intercrop or as a service-plant for nitrogen fixation). This required a broader understanding of the variables through which niches influence regimes than given by the ones offered in the MLP framework (and not only technological).

2. This framework overlooks power structures and relations. This was a case in which regime actors themselves designed technical innovations to supply niche markets. These mainstream actors had both the network connections and the power to support niche actors in organizing or to provide them with resources. They also had the capacity to influence the norms, institutional settings, and modes of regulation that formed the landscape level. However, the MLP framework does not explain these influence relationships between regime actors, niche actors, and the institutional landscape (e.g., through lobbying).

3. The implications of the ecological system's functioning are not thoroughly explored. For the authors, MLP reduces the ecological system to a biological support for technological innovations (e.g., getting the protein out of legumes) in a very restrictive way.

4. The ways in which the framework links together multiple levels was not helpful when dealing with AET. Small networks of actors alone cannot explain how nor why niches and regimes become compatible and coevolve. The authors felt it was important to understand the nature of the regime as well as its constitutive elements (e.g., a particular market or outlet, or a type of quality certification) because they are points of anchorage between niches and regimes.

In these respects, the authors found that MLP incompletely describes the ways in which the levels presented in the framework (niches, regimes, and the landscape) are connected. This, in turn, has implications for the missing variables to consider, which determines the form and boundary of the socio-technical system at hand. 


\section{Concluding remarks on study outcomes}

By examining the practical implementations of these frameworks in actual situations, these four studies deepen the understanding of the interrelations of socioeconomic, technological, and ecological factors in AET. In Table 2, we summarize the key aspects of each study, especially the research questions addressed, and some ontological factors (i.e., the time scale and contours of the system, the underlying models of change and multilevel conception, and specifying the technological, socioeconomic, and ecological system; Table 1). We also highlight the gaps and limitations of the ST framework used to analyze each AET situation (Table 2). We highlight the variety of AET and the ways they are conceptualized according to some privileged dimensions of the ST frameworks used and according to the authors' discipline and epistemological posture. In each case, we observed that ST frameworks had to be adapted to AET situations to become heuristic and operational. At a more general level, there is a need for the majority of AET case studies to ground their analyses at micro-levels, i.e., territories, individual mental models, actions, and interactions, as well as grounded collective actions.

A number of caveats remain with these studies, suggesting the need for a better understanding of the underlying models of change and their drivers. The STT studies show that we must deepen the understanding of lock-in regimes, niche-regime and landscape-niche interrelations, and the role of conflicts and power relations and changes in rules and practices. In SES studies, designing relevant conceptual models remains complex, thereby imposing limitations on their replication and scale extension (Janssen and Ostrom 2006, Étienne 2014). Another major challenge involves the need to move away from a static vision of the grammar of rules to better understand institutional dynamics and their causality in polycentric governance systems (McGinnis and Ostrom 2014). Although AET are often viewed exclusively through the lens of technological innovation, these studies also highlight the key role of social and institutional innovations in supporting such transitions. Given the diversity of possible interpretations of agroecological goals, understanding the sociopolitical debates around transition objectives and paths has to be part of any research on the subject. We found that the relative weight given to technology and technical agricultural practices, the modeling of socioeconomic systems, and the representations of the ecological system also need to be reexamined. Moreover, beyond taking into account resources as limited, the way to integrate ecological aspects remained a key issue in all these agroecosystem studies.

More generally, this examination of actual uses clearly shows that both the discipline of the researcher and the epistemology chosen were determinant for how these frameworks were used, as well as for their limitations. This illustrates how difficult it is to address the multiple aspects involved in AET while also combining STT and the SES in an integrated framework.

\section{DISCUSSION: AVENUES TO DEAL WITH THE MULTIPLE DIMENSIONS OF (AGROECOLOGICAL) TRANSITIONS}

Analyzing STT and SES frameworks through their ontologies as well as their use in field studies shows that they cannot thoroughly address the issues involved in AET. From this comparative analysis of frameworks, we highlight some key issues for further research on sustainability transitions.

\section{Strengthening a three-dimensional approach}

We confirmed that none of the frameworks fully addresses all the main dimensions involved in AET. Agroecology, defined as an ecology of sustainable food systems (Francis et al. 2003), proposes a paradigm shift in the way to analyze and manage ecological, technical, and socioeconomic aspects at multiple scales (Dalgaard et al. 2003). AET require addressing interactions among ecology, technology, and socioeconomics. The AET studies therefore revealed the difficulties that existing frameworks have in taking into account all three dimensions and exploring new interdependencies between them. Some authors have already suggested considering "socio-eco-technical systems" (Pant et al. 2015), "social-ecological-technological systems" (Olsson et al. 2014), or "socio-ecological-technological system" (McGinnis and Ostrom 2014) approaches in several kinds of sustainability transitions.

Nevertheless, views of the socioeconomic, technological, and ecological dimensions are still uneven. For instance, for many critics, the resilience approach is unappealing to the social sciences because of the misconception of socioeconomic systems resulting from the problematic application of ecological concepts to society (naturalization; Davidson 2010, Smith and Stirling 2010, Cote and Nightingale 2012, Hatt 2013, Brown 2014, Bush and Marschke 2014, Stone-Jovicich 2015). Paradoxically, as with STT, resilience thinking does not consider the ecological system as an explicit dimension in the transition process, although, at minimum, biological materiality and its specific spatial and temporal organizations should be taken into account in transition processes (Grin et al. 2010, Coenen et al. 2012, Markard et al. 2012). Achieving the integration of social and ecological interactions is still an important issue for the SES approach (Schoon and van der Leeuw 2015). In resilience thinking, technology is also weakly addressed and thus undertheorized; it is mostly seen as a mediator in human-environment interactions and exogenous to SESs (Westley et al. 2011).

By requiring three-dimensional system thinking (socioeconomic, ecological, and technical), AET emphasize the importance of exploring new interactions, which can only be partially done using the ST frameworks considered, even in a complementary way (Ostrom and Cox 2010, Olsson et al. 2014, Pant et al. 2015). We next discuss avenues for enhancing research on the coevolution of socioeconomic, ecological, and technological systems through debates about each of these dimensions.

\section{Integrating more agency into socioeconomic system thinking and} reconsidering models of change

Our analysis of different AET situations suggests that ST models of change do not fit all transition situations. We found that each framework first expresses an a priori vision with a predefined model of social change. These frameworks define both the contours of the system and the process of change by choosing the dimensions, scales, mechanisms, and type of connections considered as the main drivers of the transition.

In the vast and complex question of how to describe socioeconomic systems, power and agency must be addressed. Underestimating certain forms of agency, i.e., the ability of individuals and groups to act, define strategies, and produce new meanings, has been highlighted as a problem in critiques of STT (Geels 2010, 2011, Beymer-Farris et al. 2012) and SES studies about the way the latter deals with agency and power (Dwiartama 
and Rosin 2014, Fabinyi et al. 2014, Boonstra 2016). These debates draw partly on broader ones that have resulted from the fragmentation of the social sciences, particularly over functionalist ontology, which is the foundation of the ST frameworks considered here. By emphasizing the maintenance of order, functionalism "limits the understanding of social processes that influence change and transition, notably social dynamics, agency, and innovation" (Bush and Marschke 2014).

Some authors advocate analyzing power dynamics and asymmetries (Leach 2008, Smith and Stirling 2010, Geels 2011, Markard et al. 2012). Olsson et al. (2014) argue that adaptive management and governance concepts embed agency and power, and IAD deals explicitly with power relationships and conflict resolution. In SES studies, some research has already been done in this direction, for instance, by examining shadow networks, institutional leadership, and power issues, often using supplementary frameworks such as political ecology or actornetwork theory (Smith and Stirling 2010, Voß and Bornemann 2011, Dwiartama and Rosin 2014, Fabinyi et al. 2014, Olsson et al. 2014, Stone-Jovicich 2015, Boonstra 2016).

Current debates over the different visions of agroecology, which often oppose a model based on technological solutions to one based on ecological and social innovations, place the role of institutions and emergent collective organizations (agency) at the core of the transition process. These debates also stress the political nature of the transformations underlying these different visions. This political dimension of transition has not been sufficiently taken into account in ST frameworks (Shove and Walker 2007, Grin et al. 2010, Smith and Stirling 2010, Voß and Bornemann 2011, Brown 2014, Fabinyi et al. 2014). Some authors have identified disagreements about the transition targets (Smith and Stirling 2010, Brown 2014), the actors governing transition, the system frameworks to adopt, and the targets and means for change (Shove and Walker 2007). Other authors note that the transition process is embedded within broader political contexts that limit the possibilities for change (Voß and Bornemann 2011).

Considering agency also affects the conception of socioeconomic system change, regarding the opposition between flat and hierarchical ontologies (Geels 2011) already mentioned as well as the type of historicity, either structural-mechanistic or eventoriented (Giddens 1984). The AET studies examined here indicate that change is driven by more emergent and unpredictable dynamics, requiring more inductive and constructivist analytical approaches. The studies show that stakeholders' capacity for action is framed by institutions and that actors' choices reinforce those institutions. Individual and collective grassroots actors are key to triggering changes at the forefront of transition mechanisms; they create socioeconomic, ecological, or technological innovation processes but cannot predict the type, trajectory, and importance of the change they may trigger (Bui 2015). Therefore, following other authors and considering the potential multilevel organization of systems, we argue for more inductive, empirically grounded, constructivist (Genus and Coles 2008), and pragmatist epistemologies (Lamine et al. 2015, Popa et al. 2015, Bui et al. 2016). Such epistemologies give attention to agency within society (Leach 2008, Davidson 2010, Smith and Stirling 2010, Stone-Jovicich 2015) and also recognize the social benefits of conflicts and controversies in producing social signification, agreements, and change.

\section{Taking ecological processes into account}

The AET highlight the importance of ecology in designing agriculture that works with nature and not just avoids or limits its environmental impacts. This ecological aspect is thus a component of the system with its own agency, process, and scales. In this vision, we have to dig deeper within the properties, organization, and process of ecological systems, and not limit ourselves to the sole notions of natural resources or ecological objectives. SES frameworks are the only ones that significantly recognize ecology, biophysical materiality, and spatiality as organizing principles of the sustainability transition. However, in SESs, neither ecological processes nor the way to integrate them with socioeconomic or technological dimensions are rarely described explicitly. For instance, IAD considers natural elements as resource units described by biophysical indicators (McGinnis and Ostrom 2014) and not as ecological processes. We find that although the ecological dimension is generally absent from the STT approach, it is also paradoxically lacking within SES frameworks. This underestimation of ecological processes in ST is partly because of a historical dispute about the way that social scientists deal with nature (Caillé 2001, Bruckmeier 2011). Classical sociology does not study natural, or even technological, artefacts, considering that society is distinct from any biological determinism and that social states can only be explained by social factors (Caillé 2001). The nature-society dualism has nevertheless been questioned in various emerging approaches across the social sciences (such as political ecology, actor-network theory, etc.). These competing approaches conceptualize human-nature interactions between two polarities of tension within the social sciences: the socialization of the environment and the naturalization of society (Catton and Dunlap 1980, Caillé 2001, Bruckmeier 2011, Stone-Jovicich 2015). Some currents have developed integrative conceptions of this relationship, such as materialist-metabolic approaches (Haberl et al. 2011, González de Molina and Toledo 2014). However, they often work at a global scale and are focused on material and energy flows rather than living beings and their ideal and material aspects. In addition, political ecology considers the environment as an arena in which various social actors with asymmetrical power compete for control of natural resources (Bruckmeier 2011). Nevertheless, in all the studies, as we see with the STT and SES approaches that have particular positions on social-ecological interactions, there is debate about how to consider human and nonhuman associations symmetrically as well as how to integrate ecology (Vayda and Walters 1999, Beymer-Farris et al. 2012, StoneJovicich 2015).

AET also introduce controversies between actors about the different ways they take ecological goals into account in their management. One issue, illustrated in the Pays de Caux study, is how to address the diversity of definitions and representations of nature according to the actors and transition levels considered, and how ecology is collectively and socially constructed at the interface between the sciences and empirical knowledge. Maintaining and developing local ecological knowledge, as well as creating, reevaluating, and reshaping individual and collective management practices, rules, and organizational structures, is a continual challenge (Olsson et al. 2004). Linking socioeconomic and ecological issues, and possibilities for interdisciplinarity, means considering a limited constructivism that recognizes a nondeterminist and nonessentialist ecological materiality 
affecting humans. It also means recognizing the variability of conceptions of and interactions with such a reality (Caillé 2001, Stone-Jovicich 2015).

\section{Taking technology seriously}

Among SES scholars, there has been a growing interest in technologies, especially with the Anthropocene debate. However, until now, SES studies have considered technologies as artifacts shaped outside the SES (Westley et al. 2011). Resilience authors consider technology to be a double-edged sword: some view it as a source of destruction, whereas others question whether technical innovations can reverse the trends challenging the Earth system. However, information, nano- or biotechnologies, or geoengineering can only improve our lives if we consider ecological integrity and human needs (Westley et al. 2011, Galaz 2012). Using STT and SES frameworks, these authors propose moving beyond the technology-biosphere opposition by transforming institutions, incentives (support for institutional entrepreneurs, knowledge integration), and the supply-driven innovation system. Some IAD studies do integrate technology (Anderies et al. 2004). They consider that institutions coordinate investments in infrastructure and production technologies, which in turn influence ecosystems and production in a way that affects the relationships between users and the ecosystem. McGinnis and Ostrom (2014) suggest that IAD can also be applied to the governance of artificially constructed technological systems and can be extended to social-ecological-technical systems. On this side, STT frameworks offer the most advanced conceptualization of technology because they specifically focus on analyzing social and technological coevolution (mainly in energy and transport) because they borrow science and technology studies (STS) concepts in a systemic manner (Geels 2011).

However, ST studies actually consider large technological systems and neglect situated technical practices (Shove and Walker 2007). They also neglect the processes and scales that are involved in anchoring those practices in local territories (Coenen et al. 2012) and in actors' learning and skills development. There is also little consideration of the active role of users in shaping technology, although some STS scholars (Star 1990, Woolgar 1990) have shown how technology affects users: they may be liberated but also marginalized because of the standardized script that technology embeds, to its cost, and also to the skills it requires to be used. As McGinnis and Ostrom (2014) acknowledge, technologies create new power asymmetries and possible social cleavage given the high level of technicity necessary for technology's development and maintenance.

As for agroecology, in its strong conception, ST frameworks are insufficient because transition differs from the adoption of large, fully developed, technological packages. We advocate taking technology seriously via situated technical practices. AET need to reflect on the creation and assessment of situated technologies and technical practices, which would allow for aligning farmers' needs (technical efficiency, painfulness, profitability, etc.) and ecosystem processes with their specificities, integrity, and services supplied, as well as with societal needs and demands (health impact, food price, labor justice, etc.). If we do not consider these situated practices, reflections about the potential social or ecological impacts of technologies will remain insufficient. Doing so, however, would enable a more concrete understanding of social-ecological interactions, which is particularly crucial for AET. Technology is a constitutive element of agricultural systems. Agricultural sciences, particularly agronomy, examine interactions between ecological processes in controlled ecosystems and technologies (and technical practices) with varying degrees of complexity (Gras et al. 1989). However, farming practices cannot be reduced to a purely technological component. Some agronomists, following agroecologists (Dalgaard et al. 2003, Francis et al. 2003), broaden the concept of the traditional agroecosystem (mainly the plot) to better integrate farmers' practical knowledge, mimetism with natural ecosystems, and consideration of agroecosystems as an SES (Doré et al. 2011). Explicitly describing practices within this technical dimension requires taking into account the representations, values, knowledge, and know-how that farmers mobilize and develop in their farm management. Doing so would emphasize the individual dimension, often overlooked by ST frameworks, as crucial for innovation and new knowledge transition. Moreover, individuals may also be a source of technological or epistemic lock-in, for instance, because of risk aversion or actions of some powerful "merchants of doubt," as shown by agnotology scholars (Proctor and Schiebinger 2008, Dedieu and Jouzel 2015).

Replacing individuals in ST frameworks would also recognize the political dimension of technologies. Indeed, political agronomy, a nascent discipline inspired by political ecology and STS, studies the relationships and processes that link political, economic, and social forces with the creation and use of agronomic knowledge and technologies in terms of asymmetric power relations and struggles (Sumberg et al. 2013). In this sense, the appropriate technology movement, related to agroecology (Fressoli and Arond 2015), also seeks to redefine technology as a tool for autonomous development.

\section{CONCLUSION}

AET, and more broadly, ST, involve a great diversity of processes and aspects that cannot be encompassed in a single and integrated model or framework. We need to deepen and adjust the conceptualization of ecological, socioeconomic, and technological factors and their interconnections proposed by ST frameworks. Most previous work on these frameworks, whether combining them or not, has acknowledged the relevance of their systemic, dynamic, and multilevel approaches, yet it has also identified their limits in accounting for one of the dimensions or processes involved (such as social or ecological) and thus their limits for exploring key analytical aspects of transition (such as those linked to agency).

Moreover, STT and resilience frameworks propose a hierarchical conception of systems that strongly limits the paths through which transition can occur and the ways we think about management and governance of transition. A nonhierarchical and interdependent point of view on relationships between transition levels is central for conceptualizing transition management and governance. Considering the importance of bottom-up and adaptive processes in transition and the diversity of types of links (eco, socio, techno) between dimensions, the multilevel aspects of AET must be explored from a broader perspective. We suggest breaking away from a systematic ordering of the different transition levels in established models, the better to explore, in practice, the range of levels involved and the diversity of relationships between them, as well as their synergies. 
To study AET, we believe that there is no ready-made framework, given the internal limitations we have noted. The integration of existing ST frameworks is hampered by some ontological mismatches and by the relevance to the empirical situations analyzed. To avoid theoretical inconsistencies and blindly imposing a theoretical model on an observed situation, such a combination of ST frameworks must be carefully done and continuously grounded in empirical and diverse situations such as in the four cases we reviewed. Doing so, one must be aware of the ways in which each theory frames the way we see transition due to its ontology, beyond merely analyzing privileged dimensions. Moreover, we advocate moving beyond traditional disciplinary boundaries and epistemic postures that dictate the ways that interdependencies are studied between dimensions, scales, and the place given to empirical knowledge. Indeed, connecting transition dimensions remains challenging for the disciplinary and practical organization of research.

Sustainability transitions, in general and particularly for AET, require developing inter- and transdisciplinary dialogue, both among scientists from different disciplines and between scientists and nonscientist, plural epistemologies (Dalgaard et al. 2003, Popa et al. 2015). There is a lack of knowledge integration across the boundaries of the social and natural sciences because of the specialization of theories and their competing forms of explanation and interpretation. Beyond scientific disciplinary debates, however, transition requires increasing knowledge production through experiential learning and social learning processes within transdisciplinary research that recognize the plurality of ontologies, knowledge, and power distribution.

Responses to this article can be read online at: http://www.ecologyandsociety.org/issues/responses. $\mathrm{php} / 9952$

\section{Acknowledgments:}

We thank INRA's SAD division in giving scientific priority to studying agroecology for action, the IDAE project (ANR-15CE21-0006) for financial support, and INRA's Metaprogram Ecoserv for giving us the opportunity to publish in this issue on ecosystem services for agroecological transitions. We also thank authors of the AET studies for their contributions and Cynthia J. Johnson for editing this text in English.

\section{LITERATURE CITED}

Allison, H. E., and R. J. Hobbs. 2004. Resilience, adaptive capacity, and the "lock-in trap" of the Western Australian agricultural region. Ecology and Society 9(1):3. http://dx.doi. org/10.5751/ES-00641-090103

Altieri, M. A. 1995. Agroecology: the science of sustainable agriculture. Second edition. Intermediate Technology Publications, London, UK.

Altieri, M. A. 1999. The ecological role of biodiversity in agroecosystems. Agriculture, Ecosystems and Environment 74 (1-3):19-31. https://doi.org/10.1016/S0167-8809(99)00028-6
Anderies, J. M., M. A. Janssen, and E. Ostrom. 2004. A framework to analyze the robustness of social-ecological systems from an institutional perspective. Ecology and Society 9(1):18. http://dx. doi.org/10.5751/ES-00610-090118

Arthur, W. B. 1989. Competing technologies, increasing returns, and lock-in by historical events. Economic Journal 99 (394):116-131. http://dx.doi.org/10.2307/2234208

Berkes, F., and C. Folke, editors. 1998. Linking social and ecological systems: management pratices and social mechanisms for building resilience. Cambridge University Press, Cambridge, UK.

Berkhout, F. 2002. Technological regimes, path dependency and the environment. Global Environmental Change 12(1):1-4. http:// dx.doi.org/10.1016/S0959-3780(01)00025-5

Beymer-Farris, B. A., T. J. Bassett, and I. Bryceson. 2012. Promises and pitfalls of adaptive management in resilience thinking: the lens of political ecology. Pages 283-300 in $\mathrm{T}$. Plieninger and C. Bieling, editors. Resilience and the cultural landscape: understanding and managing change in human-shaped environments. Cambridge University Press, Cambridge, UK. http://dx.doi.org/10.1017/CBO9781139107778.020

Bijker, W. E., T. P. Hughes, and T. J. Pinch, editors. 1987. The social construction of technological systems: new directions in the sociology and history of technology. MIT Press, Cambridge, Massachusetts, USA.

Binder, C. R., J. Hinkel, P. W. G. Bots, and C. Pahl-Wostl. 2013. Comparison of frameworks for analyzing social-ecological systems. Ecology and Society 18(4):26. http://dx.doi.org/10.5751/ ES-05551-180426

Boonstra, W. J. 2016. Conceptualizing power to study socialecological interactions. Ecology and Society 21(1):21. http://dx. doi.org/10.5751/ES-07966-210121

Boyd, E., and C. Folke, editors. 2011. Adapting institutions: governance, complexity and social-ecological resilience. Cambridge University Press, Cambridge, UK. http://dx.doi.org/10.1017/ CBO9781139017237

Brown, K. 2014. Global environmental change I: a social turn for resilience? Progress in Human Geography 38(1):107-117. https:// doi.org/10.1177/0309132513498837

Bruckmeier, K. 2011. Towards interdisciplinary rural research theorizing nature-society relations. Natures Sciences Sociétés 19 (1):3-13. http://dx.doi.org/10.1051/nss/2011111

Bui, S. 2015. Pour une approche territoriale des transitions écologiques. Analyse de la transition vers l'agroécologie dans la Biovallée. Dissertation. AgroParisTech, INRA, Paris, France.

Bui, S., A. Cardona, C. Lamine, and M. Cerf. 2016. Sustainability transitions: insights on processes of niche-regime interaction and regime reconfiguration in agri-food systems. Journal of Rural Studies 48:92-103. http://dx.doi.org/10.1016/j.jrurstud.2016.10.003

Bush, S. R., and M. J. Marschke. 2014. Making social sense of aquaculture transitions. Ecology and Society 19(3):50. http://dx. doi.org/10.5751/ES-06677-190350 
Caillé, A., P. Chanial, and F. Vandenberghe. 2001. Chassez le naturel... Écologisme, naturalisme et constructivisme présentation. Revue du MAUSS 17(1):5-21. http://dx.doi. org/10.3917/rdm.017.0005

Catton, W. R. Jr., and R. E. Dunlap. 1980. A new ecological paradigm for post-exuberant sociology. American Behavioral Scientist 24(1):15-47. http://dx.doi.org/10.1177/000276428002400103

Chaffin, B. C., H. Gosnell, and B. A. Cosens. 2014. A decade of adaptive governance scholarship: synthesis and future directions. Ecology and Society 19(3):56. http://dx.doi.org/10.5751/ ES-06824-190356

Cleveland, C., R. Costanza, T. Eggertsson, L. Fortmann, B. Low, M. McKean, E. Ostrom, J. Wilson, and O. Young. 1996. A framework for modeling the linkages between ecosystems and human systems. Beijer Discussion Paper Series 76. Beijer International Institute of Ecological Economics, Royal Swedish Academy of Sciences, Stockholm, Sweden.

Coenen, L., P. Benneworth, and B. Truffer. 2012. Toward a spatial perspective on sustainability transitions. Research Policy 41 (6):968-979. http://dx.doi.org/10.1016/j.respol.2012.02.014

Cote, M., and A. J. Nightingale. 2012. Resilience thinking meets social theory: situating social change in socio-ecological systems (SES) research. Progress in Human Geography 36(4):475-489. http://dx.doi.org/10.1177/0309132511425708

Cowan, R., and P. Gunby. 1996. Sprayed to death: path dependence, lock-in and pest control strategies. Economic Journal 106(436):521-542. http://dx.doi.org/10.2307/2235561

Dalgaard, T., N. J. Hutchings, and J. R. Porter. 2003. Agroecology, scaling and interdisciplinarity. Agriculture, Ecosystems and Environment 100(1):39-51. https://doi.org/10.1016/S0167-8809 (03)00152-X

David, P. A. 1985. Clio and the economics of QWERTY. American Economic Review 75(2):332-337. [online] URL: http://www.jstor. org/stable/1805621

Davidson, D. J. 2010. The applicability of the concept of resilience to social systems: some sources of optimism and nagging doubts. Society and Natural Resources 23(12):1135-1149. http://dx.doi. org/10.1080/08941921003652940

Deconchat, M., A. Gibon, A. Cabanettes, G. du Bus de Warnaffe, M. Hewison, E. Garine, A. Gavaland, J.-P. Lacombe, S. Ladet, C. Monteil, A. Ouin, J.-P. Sarthou, A. Sourdil, and G. Balent. 2007. How to set up a research framework to analyze socialecological interactive processes in a rural landscape. Ecology and Society 12(1):15. [online] URL: http://www.ecologyandsociety. org/vol12/iss1/art15/

Dedieu, F., and J.-N. Jouzel. 2015. Comment ignorer ce que l'on sait? La domestication des savoirs inconfortables sur les intoxications des agriculteurs par les pesticides. Revue Française de Sociologie 56(1):105-133.

Doré, T., D. Makowski, E. Malézieux, N. Munier-Jolain, M. Tchamitchian, and P. Tittonell. 2011. Facing up to the paradigm of ecological intensification in agronomy: revisiting methods, concepts and knowledge. European Journal of Agronomy 34 (4):197-210. http://dx.doi.org/10.1016/j.eja.2011.02.006
Dosi, G. 1982. Technological paradigms and technological trajectories: a suggested interpretation of the determinants and directions of technical change. Research Policy 11(3):147-162. https://doi.org/10.1016/0048-7333(82)90016-6

Duru, M., M. Fares, and O. Therond. 2014. Un cadre conceptuel pour penser maintenant (et organiser demain) la transition agroécologique de l'agriculture dans les territoires. Cahiers Agricultures 23(2):84-95. https://doi.org/10.1684/agr.2014.0691

Dwiartama, A., and C. Rosin. 2014. Exploring agency beyond humans: the compatibility of Actor-Network Theory (ANT) and resilience thinking. Ecology and Society 19(3):28. http://dx.doi. org/10.5751/ES-06805-190328

Étienne, M., editor 2014. Companion modelling: a participatory approach to support sustainable development. Springer, Dordrecht, The Netherlands.

Fabinyi, M., L. Evans, and S. J. Foale. 2014. Social-ecological systems, social diversity, and power: insights from anthropology and political ecology. Ecology and Society 19(4):28. http://dx.doi. org/10.5751/ES-07029-190428

Folke, C. 2006. Resilience: the emergence of a perspective for social-ecological systems analyses. Global Environmental Change 16(3):253-267. http://dx.doi.org/10.1016/j.gloenvcha.2006.04.002

Folke, C., S. R. Carpenter, B. Walker, M. Scheffer, T. Chapin, and J. Rockström. 2010. Resilience thinking: integrating resilience, adaptability and transformability. Ecology and Society 15(4):20. http://dx.doi.org/10.5751/ES-03610-150420

Folke, C., T. Hahn, P. Olsson, and J. Norberg. 2005. Adaptive governance of social-ecological systems. Annual Review of Environment and Resources 30:441-473. http://dx.doi.org/10.1146/ annurev.energy.30.050504.144511

Foxon, T. J. 2011. A coevolutionary framework for analysing a transition to a sustainable low carbon economy. Ecological Economics 70(12):2258-2267. http://dx.doi.org/10.1016/j. ecolecon.2011.07.014

Francis, C., G. Lieblein, S. Gliessman, T. A. Breland, N. Creamer, R. Harwood, L. Salomonsson, J. Helenius, D. Rickerl, R. Salvador, M. Wiedenhoeft, S. Simmons, P. Allen, M. Altieri, C. Flora, and R. Poincelot. 2003. Agroecology: the ecology of food systems. Journal of Sustainable Agriculture 22(3):99-118. http:// dx.doi.org/10.1300/J064v22n03 10

Fressoli, M., and E. Arond. 2015. Technology for autonomy and resistance: the appropriate technology movement in South America. STEPS Working Paper 87. STEPS Centre, Brighton, UK. [online] URL: http://steps-centre.org/wp-content/uploads/AppropriateTechnology.pdf

Galaz, V. 2012. Geo-engineering, governance, and socialecological systems: critical issues and joint research needs. Ecology and Society 17(1):24. http://dx.doi.org/10.5751/ ES-04677-170124

Geels, F. W. 2002. Technological transitions as evolutionary reconfiguration processes: a multi-level perspective and a casestudy. Research Policy 31(8-9):1257-1274. http://dx.doi. org/10.1016/S0048-7333(02)00062-8 
Geels, F. W. 2010. Ontologies, socio-technical transitions (to sustainability), and the multi-level perspective. Research Policy 39 (4):495-510. http://dx.doi.org/10.1016/i.respol.2010.01.022

Geels, F. W. 2011. The multi-level perspective on sustainability transitions: responses to seven criticisms. Environmental Innovation and Societal Transitions 1(1):24-40. http://dx.doi. org/10.1016/j.eist.2011.02.002

Geels, F. W. 2014. Regime resistance against low-carbon transitions: introducing politics and power into the multi-level perspective. Theory, Culture and Society 31(5):21-40. http://dx. doi.org/10.1177/0263276414531627

Genus, A., and A.-M. Coles. 2008. Rethinking the multi-level perspective of technological transitions. Research Policy 37 (9):1436-1445. http://dx.doi.org/10.1016/j.respol.2008.05.006

Giddens, A. 1984. The constitution of society: outline of the theory of structuration. Polity Press, Cambridge, UK.

Gliessman, S. 2011. Transforming food systems to sustainability with agroecology. Journal of Sustainable Agriculture 35 (8):823-825. http://dx.doi.org/10.1080/10440046.2011.611585

Gliessman, S. R., and M. Rosemeyer, editors. 2010. The conversion to sustainable agriculture: principles, processes, and practices. CRC Press, Boca Raton, Florida, USA. http://dx.doi.org/10.1201/9781420003598

González de Molina, M., and V. M. Toledo. 2014. The social metabolism: a socio-ecological theory of historical change. Springer, Cham, Switzerland. https://doi.org/10.1007/978-3-319-06358-4

Gras, R., M. Benoit, J. P. Deffontaines, M. Duru, M. Lafarge, A. Langlet, and P. L. Osty. 1989. Le fait technique en agronomie: activité agricole, concepts et méthodes d'étude. L'Harmattan, Paris, France.

Grin, J., J. Rotmans, and J. Schot. 2010. Transitions to sustainable development: new directions in the study of long term transformative change. Routledge, New York, New York, USA.

Gunderson, L. H., and C. S. Holling, editors. 2002. Panarchy: understanding transformations in human and natural systems. Island Press, Washington, D.C., USA.

Gunderson, L. H., C. S. Holling, and S. S. Light, editors. 1995. Barriers and bridges to the renewal of ecosystems and institutions. Columbia University Press, New York, New York, USA.

Haberl, H., M. Fischer-Kowalski, F. Krausmann, J. MartinezAlier, and V. Winiwarter. 2011. A socio-metabolic transition towards sustainability? Challenges for another Great Transformation. Sustainable Development 19(1):1-14. http://dx. doi.org/10.1002/sd.410

Hatt, K. 2013. Social attractors: a proposal to enhance "resilience thinking" about the social. Society and Natural Resources 26 (1):30-43. http://dx.doi.org/10.1080/08941920.2012.695859

Hill, S. B., and R. J. MacRae. 1996. Conceptual framework for the transition from conventional to sustainable agriculture. Journal of Sustainable Agriculture 7(1):81-87. http://dx.doi. org/10.1300/J064v07n01 07
Holling, C. S. 1973. Resilience and stability of ecological systems. Annual Review of Ecology and Systematics 4:1-23. http://dx.doi. org/10.1146/annurev.es.04.110173.000245

Holling, C. S. 1978. Myth of ecological stability: resilience and the problem of failure. Pages 93-106 in C. F. Smart and W. T. Stanbury, editors. Studies on crisis management. Institute for Research on Public Policy, Toronto, and Butterworth \& Co., Montreal, Canada.

Holling, C. S. 1986. The resilience of terrestrial ecosystems: local surprise and global change. Pages 292-316 in W. C. Clark and R. E. Munn, editors. Sustainable development of the biosphere: interactions between the world economy and the global environment. Cambridge University Press, Cambridge, UK.

Holling, C. S., and G. K. Meffe. 1996. Command and control and the pathology of natural resource management. Conservation Biology 10(2):328-337. http://dx.doi.org/10.1046/ j.1523-1739.1996.10020328.x

Hughes, T. P. 1983. Networks of power: electrification in Western society, 1880-1930. Johns Hopkins University Press, Baltimore, Maryland, USA.

IAASTD. 2009. International assessment of agricultural knowledge, science and technology for development: global report. B. D. McIntyre, H. R. Herren, J. Wakhungu, and R. T. Watson, editors. Island Press, Washington, D.C., USA. [online] URL: http://www.fao.org/fileadmin/templates/est/Investment/ Agriculture at a Crossroads Global Report IAASTD.pdf

Janssen, M. A., and E. Ostrom. 2006. Empirically based, agentbased models. Ecology and Society 11(2):37. http://dx.doi. org/10.5751/ES-01861-110237

Kajikawa, Y., F. Tacoa, and K. Yamaguchi. 2014. Sustainability science: the changing landscape of sustainability research. Sustainability Science 9(4):431-438. http://dx.doi.org/10.1007/ s11625-014-0244-X

Krausmann, F., and M. Fischer-Kowalski. 2013. Global sociometabolic transitions. Pages 339-365 in S. J. Singh, H. Haberl, M. Chertow, M. Mirtl, and M. Schmid, editors. Long term socioecological research: studies in society-nature interactions across spatial and temporal scales. Springer, Dordrecht, The Netherlands. http://dx.doi.org/10.1007/978-94-007-1177-8 15

Kremen, C., A. Iles, and C. Bacon. 2012. Diversified farming systems: an agroecological, systems-based alternative to modern industrial agriculture. Ecology and Society 17(4):44. http://dx.doi. org/10.5751/ES-05103-170444

Lamine, C. 2011. Transition pathways towards a robust ecologization of agriculture and the need for system redesign. Cases from organic farming and IPM. Journal of Rural Studies 27(2):209-219. https://doi.org/10.1016/j.jrurstud.2011.02.001

Lamine, C. 2012. «Changer de système»: une analyse des transitions vers l'agriculture biologique à l'échelle des systèmes agri-alimentaires territoriaux. Terrains et Travaux 20(1):139-156. [online] URL: https://www.cairn.info/revue-terrains-et-travaux-2012-1page-139.htm 
Lamine, C., S. Bui, and G. Ollivier. 2015. Pour une approche systémique et pragmatique de la transition écologique des systèmes agri-alimentaires. Cahiers de Recherche Sociologique 58:73-94. http://dx.doi.org/10.7202/1036208ar

Leach, M., editor. 2008. Re-framing resilience: a symposium report. STEPS Working Paper 13. STEPS Centre, Brighton, UK. [online] URL: https://steps-centre.org/wp-content/uploads/Resilience. pdf

Magrini, M.-B., M. Anton, C. Cholez, G. Corre-Hellou, G. Duc, M.-H. Jeuffroy, J.-M. Meynard, E. Pelzer, A.-S. Voisin, and S. Walrand. 2016. Why are grain-legumes rarely present in cropping systems despite their environmental and nutritional benefits? Analyzing lock-in in the French agrifood system. Ecological Economics 126:152-162. http://dx.doi.org/10.1016/j.ecolecon.2016.03.024

Markard, J., R. Raven, and B. Truffer. 2012. Sustainability transitions: an emerging field of research and its prospects. Research Policy 41(6):955-967. http://dx.doi.org/10.1016/j. respol.2012.02.013

McGinnis, M. D., and E. Ostrom. 2014. Social-ecological system framework: initial changes and continuing challenges. Ecology and Society 19(2):30. http://dx.doi.org/10.5751/ES-06387-190230

Moore, M.-L., O. Tjornbo, E. Enfors, C. Knapp, J. Hodbod, J. A. Baggio, A. Norström, P. Olsson, and D. Biggs. 2014. Studying the complexity of change: toward an analytical framework for understanding deliberate social-ecological transformations. Ecology and Society 19(4):54. http://dx.doi.org/10.5751/ ES-06966-190454

Nelson, R. R., and S. G. Winter. 2002. Evolutionary theorizing in economics. Journal of Economic Perspectives 16(2):23-46. http://dx.doi.org/10.1257/0895330027247

Nicholls, C. I., M. A. Altieri, and L. Vazquez. 2016. Agroecology: principles for the conversion and redesign of farming systems. Journal of Ecosystem and Ecography S5:010. http://dx.doi. org/10.4172/2157-7625.S5-010

North, D. C. 1990. Institutions, institutional change and economic performance. Cambridge University Press, Cambridge, UK. http://dx.doi.org/10.1017/CBO9780511808678

Ollivier, G. 2015. Les communautés scientifiques de la transition agroécologique. Report for the Agroecological Transition Taskforce, INRA SAD, Avignon, France. http://dx.doi. org/10.13140/RG.2.1.5092.1686

Olsson, P., C. Folke, and F. Berkes. 2004. Adaptive comanagement for building resilience in social-ecological systems. Environmental Management 34(1):75-90. http://dx.doi.org/10.1007/s00267-003-0101-7

Olsson, P., V. Galaz, and W. J. Boonstra. 2014. Sustainability transformations: a resilience perspective. Ecology and Society 19 (4):1. http://dx.doi.org/10.5751/ES-06799-190401

Ostrom, E. 1993. The evolution of norms, rules, and rights. Beijer International Institute of Ecological Economics, Royal Swedish Academy of Sciences, Stockholm, Sweden.

Ostrom, E. 2007. A diagnostic approach for going beyond panaceas. Proceedings of the National Academy of Sciences 104 (39):15181-15187. https://doi.org/10.1073/pnas.0702288104
Ostrom, E. 2009. A general framework for analyzing sustainability of social-ecological systems. Science 325 (5939):419-422. http://dx.doi.org/10.1126/science.1172133

Ostrom, E. 2010. Beyond markets and states: polycentric governance of complex economic systems. American Economic Review 100(3):641-672. http://dx.doi.org/10.1257/aer.100.3.641

Ostrom, E., and M. Cox. 2010. Moving beyond panaceas: a multitiered diagnostic approach for social-ecological analysis. Environmental Conservation 37(4):451-463. http://dx.doi.org/10.1017/ $\underline{\mathrm{S} 0376892910000834}$

Pahl-Wostl, C., J. Sendzimir, P. Jeffrey, J. Aerts, G. Berkamp, and K. Cross. 2007. Managing change toward adaptive water management through social learning. Ecology and Society 12 (2):30. http://dx.doi.org/10.5751/ES-02147-120230

Pant, L. P., B. Adhikari, and K. K. Bhattarai. 2015. Adaptive transition for transformations to sustainability in developing countries. Current Opinion in Environmental Sustainability 14:206-212. http://dx.doi.org/10.1016/j.cosust.2015.07.006

Plumecocq, G., T. Debril, M. Duru, M.-B. Magrini, J. P. Sarthou, and O. Therond. 2018. The plurality of values in sustainable agriculture models: diverse lock-in and co-evolution patterns. Ecology and Society 23(1):21. https://doi.org/10.5751/ES-09881-230121

Popa, F., M. Guillermin, and T. Dedeurwaerdere. 2015. A pragmatist approach to transdisciplinarity in sustainability research: from complex systems theory to reflexive science. Futures 65:45-56. http://dx.doi.org/10.1016/j.futures.2014.02.002

Proctor, R. N., and L. Schiebinger, editors. 2008. Agnotology: the making and unmaking of ignorance. Stanford University Press, Stanford, California, USA.

Rotmans, J., R. Kemp, and M. van Asselt. 2001. More evolution than revolution: transition management in public policy. Foresight 3(1):15-31. http://dx.doi.org/10.1108/14636680110803003

Scheffer, M. 2009. Critical transitions in nature and society. Princeton University Press, Princeton, New Jersey, USA.

Schoon, M., and S. van der Leeuw. 2015. The shift toward socialecological systems perspectives: insights into the human-nature relationship. Natures Sciences Sociétés 23(2):166-174. http://dx. doi.org/10.1051/nss/2015034

Schot, J., and F. W. Geels. 2007. Niches in evolutionary theories of technical change: a critical survey of the literature. Journal of Evolutionary Economics 17(5):605-622. http://dx.doi.org/10.1007/ $\underline{\mathrm{s} 00191-007-0057-5}$

Shove, E., and G. Walker. 2007. CAUTION! Transitions ahead: politics, practice, and sustainable transition management. Environment and Planning $A$ 39(4):763-770. http://dx.doi. org/10.1068/a39310

Smith, A., and A. Stirling. 2010. The politics of social-ecological resilience and sustainable socio-technical transitions. Ecology and Society 15(1):11. http://dx.doi.org/10.5751/ES-03218-150111

Souchère, V., L. Millair, J. Echeverria, F. Bousquet, C. Le Page, and M. Etienne. 2010. Co-constructing with stakeholders a roleplaying game to initiate collective management of erosive runoff 
risks at the watershed scale. Environmental Modelling and Software 25(11):1359-1370. http://dx.doi.org/10.1016/j. envsoft.2009.03.002

Star, S. L. 1990. Power, technology and the phenomenology of conventions: on being allergic to onions. Sociological Review 38 (S1):26-56. http://dx.doi.org/10.1111/j.1467-954X.1990.tb03347. $\underline{\mathrm{X}}$

Stone-Jovicich, S. 2015. Probing the interfaces between the social sciences and social-ecological resilience: insights from integrative and hybrid perspectives in the social sciences. Ecology and Society 20(2):25. http://dx.doi.org/10.5751/ES-07347-200225

Sumberg, J., J. Thompson, and P. Woodhouse. 2013. Why agronomy in the developing world has become contentious. Agriculture and Human Values 30(1):71-83. http://dx.doi. org/10.1007/s10460-012-9376-8

van den Bergh, J. C. J. M., B. Truffer, and G. Kallis. 2011. Environmental innovation and societal transitions: introduction and overview. Environmental Innovation and Societal Transitions 1(1):1-23. http://dx.doi.org/10.1016/j.eist.2011.04.010

van der Brugge, R., and R. van Raak. 2007. Facing the adaptive management challenge: insights from transition management. Ecology and Society 12(2):33. http://dx.doi.org/10.5751/ ES-02227-120233

Vanloqueren, G., and P. V. Baret. 2008. Why are ecological, lowinput, multi-resistant wheat cultivars slow to develop commercially? A Belgian agricultural 'lock-in' case study. Ecological Economics 66(2-3):436-446. http://dx.doi.org/10.1016/ j.ecolecon.2007.10.007

Vayda, A. P., and B. B. Walters. 1999. Against political ecology. Human Ecology 27(1):167-179. [online] URL: http://www.jstor. org/stable/4603312

Voß, J.-P., and B. Bornemann. 2011. The politics of reflexive governance: challenges for designing adaptive management and transition management. Ecology and Society 16(2):9. [online] URL: http://www.ecologyandsociety.org/vol16/iss2/art9/

Walker, B., C. S. Holling, S. R. Carpenter, and A. Kinzig. 2004. Resilience, adaptability and transformability in social-ecological systems. Ecology and Society 9(2):5. http://dx.doi.org/10.5751/ ES-00650-090205

Westley, F., P. Olsson, C. Folke, T. Homer-Dixon, H. Vredenburg, D. Loorbach, J. Thompson, M. Nilsson, E. Lambin, J. Sendzimir, B. Banerjee, V. Galaz, and S. van der Leeuw. 2011. Tipping toward sustainability: emerging pathways of transformation. Ambio 40 (7):762-780. http://dx.doi.org/10.1007/s13280-011-0186-9

Williamson, O. E. 1996. The mechanisms of governance. Oxford University Press, New York, New York, USA.

Woolgar, S. 1990. Configuring the user: the case of usability trials. Socological Review 38(S1):58-99. http://dx.doi.org/10.1111/ j.1467-954X.1990.tb03349.x

$\mathrm{Xu}$, L., and D. Marinova. 2013. Resilience thinking: a bibliometric analysis of socio-ecological research. Scientometrics 96(3):911-927. http://dx.doi.org/10.1007/s11192-013-0957-0

Young, O. R., F. Berkhout, G. C. Gallopin, M. A. Janssen, E.
Ostrom, and S. van der Leeuw. 2006. The globalization of socioecological systems: an agenda for scientific research. Global Environmental Change 16(3):304-316. http://dx.doi.org/10.1016/ j.gloenvcha.2006.03.004 